\title{
Mikrofinans Programlarının Kadın Yoksulluğu ve Girişimciliği Üzerine Etkileri: Bir Araştırma ve Bir İşbirliği Modeli Önerisi
}

\section{Micro-finance Programs Impact on Women's Poverty and Entrepreneurship: a Survey and a Cooperation Model Proposal}

\section{Gülfem TÖMEN * Fulya SARVAN **}

\begin{abstract}
Öz: Bu çalışmanın amacı, kadın yoksulluğuna bir çözüm olarak düşünülen ve kadın girişimciliğini geliştirmesi beklenen mikrofinans programlarının, hedeflerini ne ölçüde gerçekleştirdiklerini irdelemektir. Bu amaçla kadın yoksulluğu ile ilgili literatür incelenerek Antalya'da Türkiye Grameen Mikrofinans Programı'ndan (TGMP) yararlanan kadınlar üzerine yürütülen bir saha çalışmasının nicel ve nitel bulguları raporlanmıştır. Araştırmanın saha çalışmasında yüz yüze görüşme yapılan 67 kadının büyük çoğunluğunun aileleri ile birlikte açlık sınırı ile yoksulluk sınırı arasında, genellikle kiralık bir evde yaşamakta oldukları, temel gıda maddelerini almakta zorlandıkları, mikrokredi ile evde el becerisine dayalı ürünler ürettikleri veya hazır ürünler satmakta oldukları ve mikrokredi kullanımının bu kadınları henüz yoksulluktan kurtarmaya veya girişimci yapmaya yeterli olmadığ tespit edilmiş ve mikrofinans programlarını etkili kılacak bir Kadın Girişimciliğini Geliştirme İşbirliği Modeli sunulmuştur.
\end{abstract}

Anahtar sözcükler: Mikrokredi, Kadın Yoksulluğu, Kadın Girişimciliği, Türkiye Grameen Mikrofinans Programı (TGMP)

\begin{abstract}
The purpose of this study was to question to what extent micro-finance programs, expected to bring a solution to women's poverty and to improve women's entrepreneurship, realize their objectives. To this purpose the literature on women's poverty is briefly reviewed, and the quantitative and qualitative findings of a field study of the women who used micro-credits from the Turkish Grameen Microfinance Program (TGMP) in Antalya are reported. The field study showed that the great majority of the 67 interviewed women lived together with their families, between hunger and the poverty level, mostly in rented houses, having difficulty in buying goods for their basic needs. They used micro-credits for producing hand-made goods at home, or for selling ready made goods, and the micro-credits used did not suffice to save these women from poverty, nor did using micro-credits turn them into entrepreneurs. In addition to presenting the results obtained from the field study, a Cooperation Model for Developing Women's Entrepreneurship is presented.
\end{abstract}

Keywords: Micro-credit, Women's Poverty, Women's Entrepreneurship, Turkey Grameen Microfinance Program (TGMP)

\section{Giriş}

Uluslararası çalışmalar küresel yoksulluğun giderek arttığını ortaya koymaktadır (Altay 2007, 66-67). Küresel düzeyde reel ve finansal piyasalardan elde edilen kaynaklar giderek daha

\footnotetext{
* Doktora Öğr., Akdeniz Üniversitesi, İ̈BF, Kamu Yönetimi Programı, Antalya. gulfemtomen@hotmail.com

** Prof. Dr., Akdeniz Üniversitesi, İ̇BF, İşletme Bölümü, Antalya. fulyas@akdeniz.edu.tr
} 
adaletsiz dağılmakta, küresel akımların ve gelişmelerin neden olduğu işsizlik, sosyal dışlanma, kaynakların yanlış kullanılması ile azalan ulusal ve kişi başına gelirle sonuçlanmaktadır. Bununla birlikte, yoksullukla mücadele hiçbir zaman dünya ve ülke gündemlerinin birinci konusu olamamış, yoksulluk daha çok büyüme ve kalkınma ile ilişkilendirilmiş, bu süreçlerin hızlandırılması ile büyüyen pastadan daha çok insanın pay alacağı ve böylece yoksulluğun azalacağı varsayımları yapılmıştır. Ancak büyüyen pastadan daha çok insan pay alırken bu sürece dahil olamayan birçok yeni yoksul da topluma dahil olmaktadır. Bu yeni yoksulların önemli bir oranının kadın olduğunu ileri süren Balkır ve Apaydın (2011 13-14) dünyada 1,3 milyar insanın mutlak yoksulluk sınırının altında yaşadığına ve bunların \%70'inin kadın olduğuna; Türkiye'de ise nüfusun \%43'ünün temel beslenme ve diğer asgari ihtiyaçların karşılanması için gerekli gelirin altında yaşadığına ve nispi yoksulluk içinde yaşayan 27 milyon nüfusun üçte ikisinin kadın olduğuna dikkat çekmektedirler.

2001 yılında hazırlanan Sekizinci Beş Yıllık Kalkınma Planı, Gelir Dağılımının İyileştirilmesi ve Yoksullukla Mücadele Özel İhtisas Raporu'na göre:

1. Türkiye'de gelir getiren fertlerin \%36'sı kadın, \%64'ü erkektir. Buna karşılık, yaratılan gelirin sadece \%12'si kadınlara, \%88'i erkeklere aittir.

2. Erkeklerde fert başına düşen ortalama gelir, kadınlar için fert başına ortalama gelirin 4.2 katıdır.

3. Gerek kadınlarda gerekse erkeklerde ortalama geliri en düşük olan grup, okuryazar olup bir okul bitirmeyenlerdir. Bu grupta bile erkeklerin elde ettiği gelir kadınların neredeyse 10 katıdır.

4. En yüksek gelirli grup olan lisansüstü dereceli kadınlar ve erkekler grubunda dahi, kadınlar erkeklerin ancak yarısı kadar gelir elde etmektedir.

Ecevit (2001) büyük bir toplumsal dönüşüm geçiren ve nüfusun önemli bir kısmı kırsal alanda yaşayan bir tarım toplumu olmaktan çıkan ülkemizde, yoksulluğun yapısına dikkat çekmektedir. Yazara göre, tarımdan kopuş, sanayi sektörünün istihdamın ana öğesi olmaktan çıkması ve hizmet sektörünün nitelikli istihdam sağlamada ana sektör haline gelmesi ile birlikte, kadınların yoksulluğu da yeni bir boyut kazanmıştır. Ekonomik şartların yetersizliği ve işsizlik gibi sebeplerden kaynaklı, kırdan kentlere göç etmiş ve arzuladığı refah düzeyine ulaşamamış, kentlerin olanaklarından yararlanamayan ve kentten uzak alanlara kendi olanaklarıyla yapmış oldukları gecekondularda yaşam mücadelesi veren kent yoksullarının en mağdurlarını kadınlar oluşturmaktadır. Göçle büyük şehirlere gelen nüfusun, sadece vasıfsız değil, aynı zamanda kentsel yaşama uyum sağlamakta güçlük çeken bir kesim olduğu görülmektedir.

Küresel düzeyde yeni bir görünüm ile ortaya çıkan kadın yoksulluğuna, yoksulluğun kadınlaşması adı verilmektedir. Kümbetoğlu'na (2002 129) göre, kadınlar erkeklere göre yoksulluğu farklı biçimde yaşamakta, farklı algılamakta ve farklı stratejiler geliştirmektedirler. 1970'lerden önceki yoksulluk çalışmalarında cinsiyet temelli bir yaklaşım geliştirilmemiş, yoksulluk incelenirken hane dikkate alınmış ve bütün yoksullar aynı açıdan değerlendirilmiştir. Yoksulluğu kadın açısından ele alan çalışmalar 1970'lerden sonra başlamıştır. Cinsiyet temelinde ayrımlaşmış bir yoksulluk çözümlemesi, gelişme ve refahın farklı ülkelerdeki gerçekliğini çok daha iyi anlamaya yardım etmiştir. Kadınların yoksulluğu derin yaşamalarının sebepleri, işgücüne katılmada daha dezavantajlı konumda olmaları, eğitim olanaklarından daha az yararlanmaları, kadının çalışmasının önündeki engeller, düşük ücretler, elde ettikleri gelirin denetiminde yeterli söz haklarının olmaması gibi faktörlerdir.

1995 yılında Pekin 4. Dünya Kadın Konferansı'nda kabul edilen Pekin Eylem Platformu'nda 
yoksulluğun kadınlaşması kavramı yoğun olarak kullanılmışıı. Pekin Konferansından sonra, kadın ve yoksulluk konusunda yapılan analizlerin kilit kavramı haline gelen bu terim şu olgulara işaret etmek için kullanılmaktadır (Ecevit 2003, 85): Erkeklerle kıyaslandığında, kadınların yoksullukla karşılaşma olasılıkları daha yüksektir; kadın yoksulluğu erkek yoksulluğundan daha ciddidir ve kadınlar arasında yoksulluk erkekler arasında görülene göre zaman içinde daha hızlı artmaktadır. Ayrıca, “mülkiyet üzerinde fazla söz hakkına sahip olamamaları, kaynakları kullanmada ve değer üretmede eşitsiz muamele görmeleri, ekonomik ve politik kurumlarda yaşadıkları sosyal dışlanma gibi etmenler de onların yoksulluğunu önemli ölçüde etkilemektedir”. Bu konferansta hükümetler, kadınların yoksulluğunun, erkeklerinkiyle kıyaslanamayacak kadar hızlı arttığını kabul ederek geleceğe yönelik stratejik amaçlar belirlemişlerdir. Bu stratejik amaçlar çerçevesinde dünyanın birçok ülkesinde kadın yoksulluğunu azaltmaya, kadının toplum içindeki sosyal ve ekonomik statüsünü güçlendirmeye yönelik pek çok politika ve program geliştirilmiştir. Kadının ekonomik durumunu güçlendirmeye yönelik programlar içinde kadın girişimciliğini geliştirmeye ve desteklemeye yönelik programlar önemli bir yer tutmaktadır. Bu programlar arasında birçok gelişmekte olan ülkede yaygın bir şekilde kabul gören kadınlara yönelik mikrofinans programlarının özel bir önemi vardır.

Dünyada ve Türkiye'de birbirinden farklı mikrofinans programları uygulanmakla birlikte en yaygın ve en etkin uygulanan program Grameen Bank tarafından başlatılandır (Türkiye Kalkınma Bankası A.Ş. 2007). İlk uygulaması 1976 yılında Bangladeş'de Dr. Muhammed Yunus tarafından bir sosyal girişimcilik modeli çerçevesinde geliştirilen mikrofinans programlarının kadın yoksulluğunu azaltmada çok etkili bir araç olduğu ileri sürülmektedir. Bu başarısı nedeniyle Bangladeş ve Grameen Bank uygulaması özdeşleşmiş durumdadır. 2006 yılında ekonomik ve sosyal kalkınmaya yapmış oldukları katkıdan dolayı hem Muhammed Yunus hem de Grameen Bank, olayın iki eşit parçası olacak şekilde Nobel Barış Ödülüne layık görülmüşlerdir. Dr. Muhammed Yunus tarafından bu amaçla kurulan Grameen Bankası'nın başlattığı mikrofinans programları, Avrupa, Asya, Afrika ve Amerika'da uygulanmaktadır.

Türkiye Grameen Bank Projesi “Türkiye Grameen Mikrofinans Programı (TGMP)" adı altında 11 Haziran 2003 tarihinde uygulamaya konulmuştur. Türkiye İsrafı Önleme Vakfı, Diyarbakır Valiliği ve Grameen Trust'ın işbirliğiyle yürütülen proje çeşitli kişi ve kurumlardan aldığı yardım ve bağışlarla faaliyetlerine başlamıştır. Kadın yoksulluğunu azaltmak ve çözmek, kadın girişimciliğini desteklemek ve mikrokredi sağlamak üzere dünyada ve Türkiye'de birçok çalışma ve uygulama mevcut olmakla birlikte, bu çalışmaların ve uygulamaların sürekliliği ve sürdürülebilirliği, ayrıca kadın girişimciliğini geliştirme ve yoksulluğu azaltma konusundaki etkinlikleri Türkiye bağlamında yeterince araştırılmamıştır. Bu noktadan hareketle, bu çalışmanın amacı, kadın yoksulluğuna bir çözüm olarak düşünülen ve kadın girişimciliğini geliştirmesi beklenen TGM programlarının bu hedeflerini ne ölçüde gerçekleştirdiklerini irdelemek olarak belirlenmiştir. Araştırmanın saha çalışmasında Antalya'da 2011 yılından bu yana yürütülmekte olan Türkiye Grameen Mikrofinans Programının (TGMP) kredilerden yararlanan kadınların girişimciliklerini geliştirmelerine ve yoksulluktan kurtulmalarına ne ölçüde yarar sağladığı tespit edilmeye çalışılmış, araştırma bulgularına dayanılarak sistemin daha etkili işlemesini sağlayacak bir Kadın Girişimciliğini Geliştirme İşbirliği Modeli sunulmuştur.

\section{Kavramsal Çerçeve ve İlgili Alanyazın}

\section{Kadın Yoksulluğu}

TÜİK (2002) yoksulluğu, "İnsanların temel ihtiyaçlarını karşılayamama durumu” olarak 
tanımlamaktadır. Dar anlamda yoksulluk, açlıktan ölme ve barınacak yeri olmama durumu iken, geniş anlamda yoksulluk, gıda, giyim ve barınma gibi olanakları yaşamlarını devam ettirmeye yettiği halde, toplumun genel düzeyinin gerisinde kalmayı ifade eder. Topgül'e $(2013,277)$ göre ise, en genel anlamıyla yoksulluk, "gelir eksikliği-azlığına bağlı olarak, asgari yaşam düzeyini sürdürmek için gereken mal ve hizmetlerden yararlanamama ve bu durumun beraberinde getirdiği sosyal mahrumiyet geliştirme duygusu"dur. Yoksulluk ile ilgili araştırmalar kadınların erkeklere göre daha yoksul, yoksulluk deneyimlerinin de erkeklerden farklı olduğunu ortaya koymaktadır (Güneş 2011, 218). Kadın yoksulluğu, küreselleşmeyle birlikte artan teknoloji ve yeni iş sahalarının kadın istihdamı sorununu gündeme getirmesi ve kadın reisli hanelerin artmasıyla birlikte ortaya çıkan yoksulluk sorunsalına yaklaşım için kullanılan bir kavramdır (Barrientos \& Kabeer 2004, 153). Bu kavram, evlerde bulunan çoğunlukla çocuklu anneler ve tek başına yaşayan yaşı kadınlar için kullanılmaktadır. Yoksulluğun kadınlaşması küresel bir sorundur (Cömertler 2004). Kadınlar artan bir şekilde ekonomik aktörler ve hane reisi haline gelmektedir. Onların yoksulluğu küresel ekonomik büyümeyi de yavaşlatmaktadır. Ayrıca fakir ülkelerde kadının dezavantajlı konumu yıkıcı yoksulluk sarmalını, nüfus artışını ve çevresel yıkımı beslemektedir. Sınırların bulanık hale geldiği günümüzde, kadın yoksulluğu refahın ortasında kuşatılmış yoksulluk bölgeleri, gelişmiş ülkeler üzerinde artan baskılar oluşturmaktadır.

Kadınların yoksulluğu daha derin yaşamalarının bazı sebepleri vardır: İşgücüne katılmada kadınların daha dezavantajlı konumda olmaları, eğitim olanaklarından daha az yararlanmaları, kadının çalışmasının önündeki engeller, düşük ücretler, elde ettikleri gelirin denetiminde yeterli söz haklarının olmaması gibi faktörler kadınları daha yoksul kılmaktadır. Ayrıca, mülkiyet üzerinde fazla söz hakkına sahip olamamaları, kaynakları kullanmada ve değer üretmede eşitsiz muamele görmeleri, ekonomik ve politik kurumlarda yaşadıkları sosyal dışlanma gibi etmenler de onların yoksulluğunu önemli ölçüde etkilemektedir (Ecevit 2003, 85). Bu olgunun sebepleri ile ilgili alanyazında öne çıkan faktörler aşağıda tartışılmaktadır.

Bir ülkede bireyin refahı ekonomiden alabildiği payla (geliriyle) orantılı ve o ülkenin ekonomisindeki gelir dağılımına bağlıdır. Gelir dağılımı, vergi sistemi gibi faktörlerin yanısıra, meslek, toprak ve sermaye sahipliği gibi gelir getiren değerlerin dağllımına, eğitim, sağlık hizmeti ve barınma imkanı gibi kamu mal ve hizmetlerinin sağlanması ve dağılımına bağlı olmaktadır (Yumuşak \& Bilen 2008). Bireyin ekonomik gelirden pay alabilmesi için eğitim aracılığ 1 ile elde edilebilecek bir meslek ve uzmanlığa veya toprak ve sermaye gibi gelir getirecek değerlere sahip olması gerekir. İktisatçılar, eğitim seviyesinin yükselmesini daha iyi bir gelir dağılımının ön şartlarından biri olarak kabul eder. İstatistikler, eğitim durumu yükseldikçe yoksul olma riskinin azaldığını göstermektedir. TÜİK 2009 Yoksulluk Araştırması, 2009 yılında okur - yazar olmayan veya bir okul bitiremeyenlerde yoksulluk oranını \%29,84 olarak tespit ederken, ilkokul mezunlarında \%15,34, lise ve dengi meslek okulları mezunlarında \%5,34, yüksekokul, fakülte ve üstü mezuniyete sahip olanlarda \%0,71 olarak bulmuştur (Topgül 2013, 288). Dolayısıyla eğitim firsatlarından yoksunluk doğrudan doğruya yoksulluk riski getirmektedir.

Gelir sahibi olabilmenin diğer şartları ise ya toprak vb. mülkiyete sahip olup rant geliri elde etmek ya da sermaye sahibi olup kar elde etmektir. Ulutaş $(2009,31)$ toprakların bölüşümü ve mirastan pay alma söz konusu olduğunda kadınların her zaman dezavantajlı konumda olduğuna dikkat çekmektedir. $\mathrm{Bu}$ durum kadınların kredi olanaklarına erişimini de engellemektedir. Nitekim Bircan (2002, 125 akt. Ulutaş 2009, 31) Türkiye'de aile gayrimenkullerinin kırsalda \%78'inin, kentlerde ise \%68,3'ünün erkeğin üzerine kayıtlı olduğunu, ülkede kadınların yalnızca $\% 8,7$ oranında gayrimenkul sahibi olduğunu belirtmektedir. Bu durum kadınları gelir sahibi 
olabilmenin diğer şartından da yoksun bırakmaktadır.

Türkiye Ekonomi Politikaları Araştırma Vakfı (TEPAV) adına yürütülen bir araştırmada Şener (2009, 7 akt. Topgül 2013) Türkiye'de kadın istihdamının genel özelliklerini, işgücüne düşük katılım, göçle birlikte kentlerde işgücü piyasası dışında kalma, eğitim olanaklarından yararlanamayan kadının düşük ücretlerle çalıştırılması, kırsal alanda büyük ölçüde ücretsiz aile işçisi olarak çalışmak ya da kentlerde enformel sektörde düşük ücretlerle sosyal güvencesiz çalışmak ya da ev eksenli çalışmak olarak sıralamaktadır. TÜIKK 2008 verileri de Türkiye'de istihdam edilen kadınların \%38'inin, tarımda istihdam edilen kadınların \% 74,9'unun ücretsiz aile işçisi olduğunu ortaya koymaktadır. Kadının işgücü piyasasına düşük katılımının kaçınılmaz sonucu da erkeğe bağımlılık olmaktadır (Topgül 2013, 291). TÜİK' in 2011 verileriyle istihdamdaki nüfusun \%72,3'ü erkek, \%27,8'i kadındır. İşsizlik oranı erkeklerde \%11,5 iken kadınlarda $\% 13,1$ 'dir. Türkiye'de yapılan işsizlik ve yoksulluk ilişkisine dair araştırma bulguları işsizliğin yoksullukla özdeşleştiğini göstermektedir (Mütevellioğlu \& Yirmibeşoğlu 2011).

Kadınların yaygın biçimde karşı karşıya olduğu, eğitim firsatlarından yararlanamama, istihdam dışı kalma / işsizlik, işgücüne katılmadan ev kadını olarak yaşama, kendi gelirine sahip olamama, tarımda ücretsiz aile işçisi olarak çalışma ve kentlerde enformel sektörlerde kayıt dış1 ve/veya düşük ücretlerle çalışmanın (Balkır \& Apaydın 2011, 13) sonucu olarak yoksulluğun kadınlaşması olgusunun ortaya çıktığı, kadınların yoksulluğu erkeklerden farklı biçimde deneyimledikleri görülür. "Ekonomik kaynaklara erkeklerle eşit biçimde erişemeyen, işgücüne katılamayan veya düşük ücretle, olumsuz koşullarda çalışmaya boyun eğen, eşit eğitim haklarından yararlanamayan, örgütlenerek ve adli merciler başvurarak haklarını arayamayan kadınlar, annelerinden miras kalan yoksunlukları kendi kız çocuklarına miras bırakmaktadırlar" (Ulutaş 2009, 38).

Kadınlar aynı zamanda yoksulluğun diğer bir sonucu olan sosyal dışlanma riski ile karşı karşıyadır. Sosyal dışlanma (Şahin 2009); işsizlik, gelir ve malvarlığı yetersizliği gibi ekonomik nedenler; eğitimsizlik, yaş ve cinsiyet gibi bireysel nedenler; sosyal güvence eksikliği ve toplumsal destek yoksunluğu gibi sosyal ve kurumsal nedenler ile politik haklardan yararlanamamak ve politik karar alma mekanizmalarına katılamamak gibi nedenlerle, bireyin siyasi, ekonomik ve sosyal haklarını kullanamaz duruma gelmesi, toplum ile bağlarını yitirmesi, ve toplum dışına itilmesidir. Buğra'nın $(2008,259)$ belirttiği gibi “...yoksulluk her şeyden önce insanın topluma diğer insanlar gibi katılabilmesini engelleyen bir sosyal dişlanma sorunudur”. Toplumun genelinin ulaşabildiği imkanlara ulaşamama, emek pazarının enformelleşmesi ve kayıt dışı işlerdeki artış, sosyal dışlanma ve marjinalleşme kavramının özellikleridir (Özbudun 2002, 54-55). Dolayısıyla, yoksul kadın açısından diğer bir kaçınılmaz sonuç, toplum dişında kalmak, vatandaşlara tanınan birçok haktan yeterince yararlanamamaktır.

TÜIK, 2014 Ağustos Hanehalkı İşgücü Anketi sonuçları da kadınların işgücüne katılım oranının \%27, erkeklerinkinin ise \%65.7 olduğunu göstermektedir. İşsizlik rakamlarının hesaplanma şekli iş aramakta olanları dikkate aldığı için gerçeklerin tam olarak yansıtılmasına izin vermemekle birlikte, kadınların işsizlik oranı \%12.7, erkeklerin işsizlik oranı \%8.9'dur. Kadınların işgücüne katılım oranları eğitim düzeyleriyle ilişkilendirildiğinde 2010 yılında en düşük katılım oranının okuma yazma bilmeyenler (\%16.3), okuma yazma bilen ancak bir okul bitirmemiş olanlar (\%20.4) ve ortaokul ve dengi meslek okulu bitirenlerde (\%24.6) görüldüğünü, lise (\%30.4), lise dengi meslek okulu (\%39.8) ve yüksekokul ve fakülte mezunları için (\%71) ise oldukça farklılaştığı görülmektedir (TÜíK Veri Tabanı 2012 akt. Korkmaz \& Korkut 2012, 47). Yine aynı veritabanı, medeni durum ile kadının işgücüne katılımı arasındaki ilişkiyi gösteren verilerinde, 2010 yılında işü̈cüne katılımı en düşük olan kadın grubunu evli olanlar (\%26.4) 
olarak belirlemiş, hiç evlenmemişler (\%36.6) ve boşanmış kadınların (\%47.8) işgücüne katılımı çok daha yüksek bulunmuştur.

Yoksullukla ilişkilendirilen diğer bir önemli faktör de kadınların pek çok konuda maruz kaldığı ayrımcılıktır. Kadına yönelik ayrımcılık en başta hane içerisinde kendisini göstermektedir (Körükmez 2008, 217). Aile içerisinde kız çocuklara farklı erkek çocuklara farklı davranılmakta, erkek çocuklar kız çocuklara oranla daha az baskı görmekte ve daha serbest yaşamaktadırlar. Eğitim olanaklarından yararlanmada, evin dışındaki hayata uyum sağlamada ve ev dışındaki sorumlulukları üstlenmede hep erkek çocukları ön plandadır. Kız çocukları ev içerisinde çok erken yaşlarda sorumluluk almaktadırlar. Evin dışında ise özgürlükleri son derece sınırlıdır. Çalışan kız çocukları her konuda ailenin onayını almak durumundadır, kendi kazancını istediği gibi harcayamamaktadır. Diğer yandan kız çocuklarının hane dışında çalışmaya başlamaları onların ev içindeki sorumluluklarını azaltmamaktadır.

Yukarıda açıklanan birbiriyle ilişkili ve karmaşık bir yapı arz eden kadın yoksulluğu ile mücadele için küresel ve ulusal düzeylerde çok çeşitli programlar geliştirilmiştir. Bu programların başlıcalarına aşağıda yer verilmektedir.

\section{Dünyada ve Türkiye'de Kadın Yoksulluğuna Yönelik Programlar}

Yoksulluğun tüm dünyada derinden hissedilen etkilerine karşı, çeşitli ülkelerin ulusal devlet politikaları çerçevesinde olduğu gibi uluslararası kuruluşlar düzeyinde de yoksullukla mücadele için çeşitli politika ve programlar geliştirilmiş durumdadır (Şenses 2001). Yoksulluk ile mücadele programları, kıtlık olan ülkelere doğrudan gıda yardımı, yoksulların işgücü piyasalarındaki konumlarını iyileştirmeye yönelik projeler, tarımda istihdam ve verimliliğin artırılmasına yönelik projeler, mesleki eğitim ve kredi olanaklarının yoksullara sağlanmasına yönelik projeler, yol, sulama ve ağaçlandırma gibi alanlarda düşük ücretli istihdam yaratan projeler, yoksullara küçük projelerini hayata geçirmek için verilen destek kredileri vb. projelerden oluşmaktadır.

Dünya ölçeğinde yoksullukla mücadele konusunda çalışan birçok resmi kuruluş vardır. Dünya Bankası, Birleşmiş Milletler, Asya Kalkınma Bankası, Afrika Kalkınma Bankası, InterAmerikan Kalkınma Bankası bunların başında sayılmaktadır (World Bank Food Programme Yearly Report 2004). Asya ve Afrika Kalkınma Bankaları Asya ve Afrika ölçeğinde yoksulluğun azaltılması yönünde hizmet verirlerken, Birleşmiş Milletler ve Dünya Bankası tüm dünyada yoksulluk ile mücadele sürdürmektedir. Bu kuruluşlardan Birleşmiş Milletler, yoksulluk ile mücadelesini birkaç platformda sürdürmektedir. Birleşmiş Milletler Dünya Gıda Programı, Birleşmiş Milletler Kalkınma Programı (UNDP) ve UNICEF bunlar arasındadır. Dünya Gıda Programı, tüm bu çalışmalar arasında en çok dikkat çeken ve yoksulluk ve açlığa doğrudan yardımlar ile cevap verebilen bir programdır.

Türkiye'de ise yoksullukla mücadele devlet eli ile Sosyal Yardımlaşma ve Dayanışma Teşvik Fonu (SYDTF) aracılığıyla sürdürülmektedir (www.sydgm.gov.tr). Doğrudan kadın sorunları ve kadın yoksulluğu ile ilgili politikalar geliştirmek üzere kurulan Kadının Statüsü Genel Müdürlüğü (KSGM) kadınların sosyal yaşamın her alanında güçlendirilmesine yönelik politikalar geliş̧irilmesinden ve uygulanmasından sorumludur (www.ksgm.gov.tr). Bu yönüyle, Türkiye'de toplumsal cinsiyet eşitliğini sağlamanın ulusal kurumsal mekanizması konumundadır. Genel Müdürlük, Türkiye'de kadınların genel eğitim düzeyinin yükseltilmesi; tarım, sanayi ve hizmetler alanındaki faaliyetlere katılımının artırılması; sağlık, sosyal güvenlik ve hukuk alanlarındaki güvenliğinin sağlanması ve toplumsal, ekonomik, kültürel ve siyasal açılardan eşit statü kazanmalarına yönelik politikalar geliştirilmesi ve uygulanması görevlerini üstlenmiştir.

GAP İdaresi tarafından, sürdürülebilir kalkınmanın ekonomik, sosyal ve çevresel boyutlarını 
bütünleştiren yoksulluğu azaltma stratejileri, katılımcı yaklaşımların teşvik edilmesi, kapasite geliştirmeye yönelik çalışmalar ve bütün bu çalışmalarda dezavantajlı grupların ve cinsiyet perspektifinin gözetilmesi yönünde bir dizi projeler yürütülmektedir (www.beytussebap.gov.tr). $\mathrm{Bu}$ bağlamda yürütülen çalışmaların en önemlilerinden biri Çok Amaçlı Toplum Merkezleri (ÇATOM'lar) projesidir. ÇATOM'lar, GAP İdaresi tarafindan 1992-94 yılları arasında yapılmış olan beş temel araştırmanın bulgularına dayalı olarak hazırlanmış olan Sosyal Eylem Planı ile bu araştırmalardan biri olan "GAP Bölgesinde Kadının Statüsü ve Kalkınma Sürecine Entegrasyonu Araştırması" bulgularına dayalı olarak hazırlanan Eylem Planı'ndan hareketle ortaya çıkmıştır. Çok Amaçlı Toplum Merkezleri (ÇATOM'lar), GAP Bölgesi'nde 1995 yılından itibaren açılmaya başlanmış olup halen GAP Bölgesindeki 9 ilde 30 ÇATOM mevcuttur. ÇATOM'ların hedef kitlesi genç kız ve kadınlardır. ÇATOM'larda amaç, kadınların sorunlarının farkına varmalarına, tanımlamalarına ve çözümü için inisiyatif kullanabilmelerine firsat yaratmak; kadınların kamusal alana daha fazla katılımlarını ve kamusal hizmetlerden daha fazla yararlanmalarını sağlamak; kadın istihdamını ve kadın girişimciliğini artırmak; kadını güçlendirerek firsat eşitliğinin sağlanmasına katkıda bulunmak, cinsiyet dengeli kalkınma sürecini başlatmak ve bu yolla yerel koşullara uygun, katılımeı toplum kalkınması temelli tekrarlanabilir model/modeller geliştirmektir. ÇATOM'larda temel ilke kadınlara ne yapacaklarını değil, hangi koşullarda neler yapılabileceğini göstermektir. Çeşitli alternatifler içinden seçimi yapacak olan veya yeni seçenekleri ortaya koyacak olan kadınların kendisidir.

Yine kadın yoksulluğuna yönelik çalışmalar yapan sivil toplum kuruluşlarından biri olan Kadın Emeğini Destekleme Vakfı (KEDV) "dar gelirli kadınların yaşam kalitelerini ve ekonomik durumların iyileştirmelerine destek olmak ve yerel kalkımmada liderliklerini güçlendirmek" için 1986 yılında kurulmuştur (www.kedv.org.tr). Vakıf dar gelirli kadınların uzmanlık alanlarını dikkate alan bir işbirliği ile toplumu ve dar gelirli aileleri geliştirmeyi hedeflemektedir. Bir diğer STK olan Kadın Merkezi (KAMER), 1999 yılında özel bir statüyle kurulmuş, hükümet dışı ve kar amacı gütmeyen, merkezi Diyarbakır'da olan bir sivil toplum kuruluşudur (www.kamer.org.tr). Hedefi, kadınların hukuksal, ekonomik, siyasal ve toplumsal açıdan güçlendirilmelerine katkı sağlamak ve kadınların uzun dönemli istihdamı ve eğitimi için destek mekanizmaları geliştirmektir. Diğer bir güçlü sivil toplum kuruluşu olan Kadın Dayanışma Vakfı (KADAV) ise, 1999 Marmara Depreminden zarar gören kadınları desteklemek üzere bir araya gelen bir grup kadın tarafından kurulmuştur. Amacı, kadınları güçlendirmek, kadınlar arasında dayanışma ağları oluşturmak için araçlar ve firsatlar geliştirmektir.

\section{Dünyada ve Türkiye'de Kadın Girişimciliğini Geliştirme Programları}

Dünyada kadını güçlendirmeye ve kadın yoksulluğunu ortadan kaldırmaya yönelik pek çok girişimcilik geliştirme programı vardır. Girişimciliğin, işsizlik sorununa önemli bir çözüm olanağ1 sunduğu gibi ekonomik büyümenin de önemli bir bileşeni olduğu kabul edilmektedir. Girişimci, ekonomik kaynakların düşük üretkenlik alanlarından yüksek alanlara aktarılma sürecinde baş aktördür. Ayrıca kullanılmakta olan üretim araçlarının ve mevcut girdilerin değişik şekillerde kullanımı ile üretimi artırır. Bu yönüyle girişimci toplumsal fayda yaratan ekonomik bir aktör olarak görülmekte ve ülkeler girişimciliği geliştirmeye çalışmaktadır. $\mathrm{Bu}$ çabalar içinde kadınlara yönelik olanlar daha farklı bir özellik ve önem arz ettiği için genel programların dışında kadın girişimciliğini geliştirmeye yönelik özel politikalar ve programlar geliştirilmesi gerekli olmuştur. Örneğin, Uluslararası Çalışma Örgütü (ILO) kadın girişimciliği konusunu, işgücü piyasası politikalarında kadınlara erkeklerle eşit firsatlar sağlanması bağlamında ele almaktadır (Ecevit 2007). Örgüt, Kadın Girişimciliğinin Geliştirilmesi ve Toplumsal Cinsiyet Eşitliği (WEDGE)'nin bir bileşeni olan Küçük Girişimciliği Geliştirme Programı 
(SEED) kapsamındaki çalışmaları ile girişimcilik bağlamında kadınlara destek sağlamaktadır. Uluslararası Çalışma Örgütü'nün 'Kendi İşini Kur' adıyla bilinen, ticari beceri geliştirmeyle ilgili, amacı küçük işletmeleri desteklemek olan bir uluslararası eğitim programı (eğiticilerin eğitimi) bulunmaktadır.

Avrupa Birliği üyelik görüşmeleri sürecinde Türkiye'nin AB politikalarına ve düzenlemelerine uyum sağlaması gerekmektedir. Topluluk Cinsiyet Eşitliği Programı, Topluluk Ayrımcılık Karşıtlığı Programı ve Topluluk Sosyal Dışlanmaya Karşı Mücadele Programı (www.europa. eu.int) başta olmak üzere AB'nin hazırladığı topluluk programları nedeniyle Çalışma ve Sosyal Güvenlik Bakanlığı, toplumsal cinsiyetle ilgili konulardaki çalışmalarını artırmıştır (www.csgb. gov.tr). Bakanlık, genel olarak kadın istihdamını, özel olarak da kadın girişimciliğini bu politika öncelikleri çerçevesinde değerlendirmekte ve kadın istihdamına ilişkin stratejisini de yine buna göre belirlemektedir. Bu politika öncelikleri arasında en önem verilenin, kayıt dışı istihdam ile mücadele olduğu görülmektedir.

Türkiye'de bu alandaki sivil toplum hareketine örnek olarak Kadın Girişimciler Derneği (KAGIDER) faaliyetleri gösterilebilir (http://www.kagider.org). KAGIDER İstanbul'da ve Anadolu'nun farklı illerindeki kadın girişimcilere iş kurma ve geliştirme süreçlerinde kapsamlı eğitimler sağlamanın yanı sıra, kadın girişimci adaylarına inkübasyon, danışmanlık ve mentörlük desteği sunmaktadır. Ayrıca genç kadınlar arasında farkındalık yaratma ve bilinç yükseltme çalışmaları ile onları daha iyi eğitim almaları ve iş yaşamına başarılı geçişleri yönünde desteklemektedir.

GAP Bölgesinde yatırımların artması ve girişimciliğin geliştirilmesi amacıyla yatırım konusunda danışmanlık sağlamak üzere GAP Girişimci Destekleme ve Yönlendirme Merkezleri (GAP-GIDEM) kurulmuştur (Paksoy \& Aydoğdu 2010, 126-128). Birleşmiş Milletler Kalkınma Programı (UNDP) ile birlikte yürütülen Sürdürülebilir Kalkınma Programı kapsamında 1997 sonunda başlatılan ve daha sonra ikinci aşamaya geçilen proje, bölgede açılan beş GIDEM ofisi aracılığıyla uygulanmıştır. Eylül 1997 'de Adıyaman, Diyarbakır, Gaziantep, Mardin ve Şanlıurfa illerinde GAP-GİDEM büroları açılmış ve faaliyetlere başlanmıştır.

Ayrıca, TOBB bünyesinde 2007 yılında kurulan Kadın Girişimciler Kurulu (KGK), kadın girişimciliği konusunda genel politikalar geliştiren ve görüş oluşturulmasına katkıda bulunan istişari bir kurul (www.tobb.org.tr) olarak düşünülmüştür. Kurul aynı zamanda kadın girişimcilere eğitim ve kapasite geliştirme desteği ile girişimci fikirlerini hayata geçirmelerinde destek sağlamaktadır. Kurulun görevleri, ülkemizdeki kadın girişimci potansiyelinin nicelik ve nitelik bakımından geliştirilmesi ve daha donanımlı hale getirilmesi amacıyla politika belirlemek ve girişimcilik kültürünün kadınlar arasında gelişmesine öncülük etmek, kadınlara kişisel gelişim yollarını öğreterek kariyer geliştirme firsatları yaratmaktır. Kuruluşu 29 Ekim 2007 olan TOBB Kadın Girişimciler Kurulu 2014 yılında 81 ilde teşkilatlanmasını tamamlamıştır. Oda ve borsaların koordinasyonunda faaliyetlerini yürüten TOBB KGK'nun 5.674 üyesi bulunmaktadır.

\section{Kadın Yoksulluğu ve Girişimciliğine Yönelik Sosyal Girişimcilik Programları}

"Sosyal girişim" terimi bünyesinde "sosyal” ve "girişim" olmak üzere iki farklı olguyu barındırmaktadır. Girişimcilik anlayışı beraberinde tıpkı ticari girişimlerde olduğu gibi sorun ve fırsatları fark etme, doğru değerlendirme, risk alma ve yenilikçi yollarla çözümleme olgularını getirmektedir. "Sosyallik" anlayışı ise girişimcilik prensiplerinin kar maksimizasyonu yerine toplumsal sorunlara uyarlanmasını kapsamaktadır. Böylece sosyal girişimler, sosyal sorunların çözümünde girişimcilik esaslı veya serbest piyasa temelli yöntemler benimseyen kuruluşlar olarak ortaya çıkmaktadır. Dünyada sosyal girişimlere yönelen yetenek, para ve ilgi gün geçtikçe 
artmakta, modelin rağbet görmesi ile birlikte çeşitli ulusal ve uluslararası platformlarda sosyal girişimlerin ne olduğuna ve ne yaptığına ilişkin tartışmalar yapılmaktadır (www.tüsev.org.tr).

Sosyal girişimlerin bir diğer ortak yaklaşımı sosyal sorunların çözümünde "sistematik değişimi" hedeflemeleridir. Sosyal girişimler ele aldıkları alanlarda benzer vakaları tek tek düzeltmektense sistematik değişim yaratmayı, çözümlerini yaygınlaştırmayı ve uzun vadede toplumun desteğini kazanarak sorunun ortadan kaldırılmasını hedeflerler. Bu kurumlar, üçüncü sektör diye tanımlanan, devletin dışında kalan ve kâr amacı gütmeyen örgütler ve özel sektörü temsil eden ticari girişimler/şirketler (kâr amacı güden) olarak faaliyet göstermektedir. Sınırları oldukça esnektir, bu yüzden de kâr amaçlı olan ve kâr amaçlı olmayan faaliyetleri melez bir şekilde gerçekleştirirler. Sosyal girişimleri diğer tüm örgüt formlarından ayıran en temel özellik birincil ve tek amacının sosyal misyon olmasıdır. TÜSEV'e göre, sosyal girişimler (www.tüsev.org.tr) "sosyal bir amaçla kurulur ve faaliyet gösterir, ekonomik faaliyetler yürütür, elde ettikleri karı sosyal amaçları için kullanır”. Sosyal girişim yaklaşımının diğerlerinden farkını betimlemek için kullanılan yaygın bir benzetme sosyal girişimlerin yalnızca balık vermek veya balık tutmayı öğretmekle yetinmedikleri, bunun yerine balık endüstrisini kökten değiştirmeyi hedefledikleri yönündedir (Denizalp 2009).

Dünya çapında sosyal girişimciliği destekleyen ve kâr amacı gütmeyen bir kuruluş olan Ashoka Uluslararası Sosyal Girişimciler Ağı 1980 yılında William Drayton tarafından Hindistan'da kurulmuştur (www.ashoka.org). Ashoka sağlı, eğitim, çevre, insan hakları, kalkınma ve sivil inisiyatifin geliştirilmesi alanlarında çalışan sosyal girişimcileri, kendilerini, dolayısı ile işlerini geliştirebilmeleri için uluslararası düzeyde maddi ve manevi olarak desteklemektedir. Dünyanın ilk ve en geniş sosyal girişimci ağı Ashoka, günümüzün acil toplumsal sorunlarına kalıcı çözümler getiren sosyal girişimcileri bulmakta, onları maddi manevi destekleyerek kendi potansiyellerini gerçekleştirmelerini ve çözümlerini yaygınlaştırmalarını sağlamaktadır. Ashoka, toplumsal değişimin katalizörleri olan bu bireylere 30 yıldır ev sahipliği yapmakta, 70 ülkeden 3000'i aşkın Ashoka üyesi (Ashoka Fellow) çeşitli alanlarda çalışmaktadır. Bugün aralarında Muhammed Yunus (Nobel Barış Ödülü sahibi), Jimmy Wales (Wikipedia kurucusu), Peter Eigen (Transparency International), Nasuh Mahruki (AKUT) ve İbrahim Betil'in (TOG) de bulunduğu kişiler bu unvanı taşımaktadır.

Bir sosyal girişimci olan Grameen Bank'ın kurucusu Dr. Muhammed Yunus'un hikayesi Bangladeş’teki Chittagong Üniversitesinde profesör olarak görev yaptığ 1976 y1lına kadar uzanmaktadır (Bornstein 1996, 15). Dr. Yunus, yoksul kesimin mali sistem içerisinde faaliyet gösteren bankalar vb. ticari kuruluşlardan kredi temin etmelerinin mümkün olmadığını ve bu kişilerin yerel para simsarlarının ellerinde tutsak olduklarını gözlemledikten sonra bir proje başlatmaya karar vermiştir. Projede ihtiyaç sahibi yoksul bireylere beşer kişilik gruplar oluşturmaları halinde, maddi teminat talep etmeksizin, işlerini geliştirmeleri için küçük miktarlarda krediler sağlanır (Hashemi \& Morshed 1997, 217). Projede amaç, kırsal kesimde yaşayan yoksullara kredi dağıtımını yapabilecek bir bankacılık sisteminin oluşturulmasıdır. Dr. Muhammed Yunus bu proje ile kırsal alandaki yoksulluğun önlenmesine ve bu alanların bölgesel kalkınmalarına farklı bir açıdan yaklaşarak yoksul kesime ücretli işler yaratılması yerine, onların kendi işlerine sahip olmaları ile hem ekonomik hem de sosyal açıdan arzulanan sonuçlara daha hızlı bir şekilde ulaşılabileceğini vurgulamaktadır (Rhyne 1994, 105-115). Ayrıca, yoksul kesimin kredi olanaklarından yoksun olmalarının onların temel insan ihtiyaçlarından mahrum oldukları anlamına geldiğini belirterek toplumdaki en yoksul kesimin finansal kaynaklara rahatlıkla, hiçbir maddi teminata gerek duyulmaksızın ulaşabilmelerinin gerekliliğini ortaya koymuştur. Ona göre hiç kimse parayı fakirlerden daha iyi bir şekilde yönetemez. 
Dr. Muhammed Yunus kadınların hedef müşteri kitlesi olarak seçilmesinin önemini şöyle ifade etmektedir (www.grameen-info.org): Kadınların kredi sisteminden yararlanmaları, aileye büyük faydalar sağlamaktadır. Kadınlar ailenin uzun dönemde daha güvenli bir ortamda bulunmasına daha fazla önem vermektedirler. Günümüzde Grameen Bank’ın müşterilerinin \%97'sini kadınların oluşturduğu düşünüldüğünde, Dr. Yunus'un kadınları bankanın kredi müşterisi haline getirmesinde izlediği yolun oldukça başarılı olduğu söylenebilir. Grameen Bank uygulamasında, karlılık gibi bir bankada bulunması gereken en temel öğeler korunurken, sosyal alanda toplum için gerekli adımların da atılmaya çalışıldığı, Dr. Yunus'un deyimiyle "sosyal bilince sahip bir kapitalist kuruluş” meydana getirildiği söylenebilir (Bornstein 1996).

Avrupa, Asya, Afrika ve Amerika'da uygulanmakta olan Grameen Bank Projesi, ülkemizde "Türkiye Grameen Mikrofinans Programı (TGMP)" adı altında 11 Haziran 2003 tarihinde uygulamaya konmuştur. Türkiye İsrafı Önleme Vakfı, Diyarbakır Valiliği ve Grameen Trust'ın işbirliğiyle yürütülen proje çeşitli kişi ve kurumlardan aldığı yardım ve bağışlarla faaliyetlerine başlamıştır. Projede yoksulluğun yoğun olarak görüldüğü kent merkezleri ve kırsal bölgelerde yaşayan dar gelirli ve ekilebilir bir tarım arazisi bulunmayan kadınlara kredi imkanları sağlanmaktadır. Böylelikle bir yandan kadın girişimciliğine destek olunurken, diğer yandan kadının hem aile hem de bulunduğu toplum içerisindeki sosyal statüsünün gelişmesine katkıda bulunulmaktadır. Mayıs 2014 tarihi itibariyle Türkiye'de bu bankanın sürdürdüğü TGM programindan yararlanmakta olan 63.502 kadın mevcuttur (www.tgmp.net,TGMP_23.Haziran 2014 by TGMP TISVA). Bunların 51.246's1 kredi alan üye, 12.256's1 ise kredi bekleyen üyedir. Bu program kapsamında 105 şube ve 320 personel ile faaliyetler sürdürülmekte, Haziran 2014 itibariyle toplam 317.301.862 TL kredi dağıtılmış bulunmaktadır.

Bu noktada, mevcut çalışmanın araştırma sorusunu oluşturan tartışma konusunda farklı görüşlere yer vermekte yarar vardır. Mikrokredi programları genel olarak yoksulluğu, özelde kadın yoksulluğunu hafifletmeye yardımcı olmakta mıdır? Bir CGAP makalesinde Littlefield ve diğerleri (2003), yoksul hane halklarına sağlanan finansal hizmetlerin Birleşmiş Milletlerin Milenyum Kalkınma Hedeflerinin başarılması üzerinde güçlü bir etki yarattığına ilişkin birikmekte olan kanıtları paylaşmaktadır. Bu şekilde sağlanan mikrofinansın iş kredilerinin ötesine geçip sadece mikro girişimlerin yatırımları için kullanılmakla sınırlı kalmadığı, aynı zamanda hane halklarının acil ihtiyaçlarına yanıt verdiği, sağlık ve eğitime yatırım yapıldığı ve çeşitli nakit ihtiyaçlarını karşıladığı ileri sürülmektedir. Yoksullara sağlanan finansal hizmetler içinde krediler, tasarruf imkanları, sigorta, transfer ödemeleri ve hatta mikro emeklilik gibi hizmetler de bulunmaktadır. Bu makale, Bolivya'dan Gana'ya, Endonezya'dan Hindistan'a, Zimbawe'den Bangladeş'e kadar çok sayıda ülkede yürütülen onlarca çalışmada mikrofinans programına katılan yoksulların gelir, eğitim, sağlık, beslenme, ekonomik durum, çocuklarının eğitim seviyesi gibi pek çok göstergede iyileşme yaşandığını özetlemektedir.

Ancak, Küresel Kalkınma Merkezi'nin (Center for Global Development) 2007 raporunda, mikrofinansın kredi kullanan bireyler üzerindeki dönüştürücü etkileri üzerine pek çok hikaye olmakla birlikte, yakın zamana kadar mikrofinansın etkilerini diğer faktörlerden ayırt etmeye ya da mikrofinansa değişik yaklaşımların sonuçları nasıl değiştirdiğini tespite girişen çok az sayıda güçlü araştırma yapıldığına dikkat çekilmektedir. Jamaluddin Husain (2008) mikrofinans kuruluşlarının yoksulluğu azaltma konusundaki rolünü ele alan çalışmaları değerlendirdiği makalesinde, bu kuruluşların yoksulluğun giderilmesi üzerinde etkili olduğuna ilişkin kanıtların birikmekte olduğuna dikkat çekmekte, ancak iki çeşit mikrofinans kuruluşu arasında ayırım yaparak dış yardım ve bağışlara muhtaç olan, dolayısıyla daha istikrarsız mikrofinans kuruluşlarının değil, kendi geliri olan ve ayaklarının üstünde durabilen, dolayısıyla sürdürülebilirliği 
olan kuruluşların yoksullukla mücadelede daha etkili olduğunu vurgulamaktadır.

Türkiye'nin bu konudaki deneyimini ortaya koymak üzere Diyarbakır'daki Grameen Mikrofinans Programından yararlanan 100 kadın üzerine gerçekleştirilen alan araştırmasının bulgularının (Balkız \& Öztürk 2013, 20) ortaya koyduğu tablo pek parlak değildir. Araştırma sonuçları mikro krediye başvuru kararının alınmasında erkeğin belirleyici konumda olduğunu, herhangi bir ekonomik girişimi başlatma ve bir başlangıç sermayesine erişim konusunda kadınların bağımsız karar veremediklerini; kredilerin genellikle hanedeki borçların ödenmesi ya da acil ihtiyaçların karşılanması için kullanıldığını; kredi kullanılarak yapılan işlerin geleneksel ev-içi üretim özelliği gösteren işler olup ev dışında güvenceli, düzenli gelir getiren ve kadınları kamusal hayata sokan işler olmadı̆̆ını; mikrokredi ile yapılan işten elde edilen kazancın düşüklüğünün kadının ekonomik bakımdan güçlenmesi teziyle uyuşmadığını; ailenin geçiminde erkeğin belirleyici olması ve kadının kazancının erkekle eş düzeyde olmayıp ek gelir statüsünden bir türlü kurtulamayışı nedeniyle sosyo-ekonomik bakımdan kadının statüsünde de bir değişim olmadığını göstermiştir.

Alanyazında araştırma sorusuna ilişkin yukarıda özetlenen farklı görüş ve bulguları yerelde değerlendirmek üzere Antalya ilindeki TGMP şubesinden kredi kullanan kadınlar üzerinde mikrofinans programının etkinliğini sınamayı amaçlayan bir saha çalışması tasarlanmıştır. $\mathrm{Bu}$ çalışma, mikrofinans programının sunduğu hizmetlerin yoksulluğu azaltıcı etkilerini gözlemlemek, kadınları girişimci yapma konusundaki yeterliliğini değerlendirmek ve kadınların yaptıkları işlerin sürdürülebilirliğini izlemek üzere tasarlanmıştır.

Mikrofinans Programından Yararlanan Kadınlar Üzerine Bir Araştırma (Tömen 2013)

\section{Araştırmanın Amacı}

Çalışmanın amacı, Türkiye Grameen Mikrofinans Programı (TGMP) çerçevesinde dağıtılan mikrokredilerin kadın girişimciliği ve yoksulluğu üzerindeki etkilerini araştırmaktır. Bu amaçla, Türkiye Grameen Mikrofinans Programı Antalya Şubesinin mikrokredi programından faydalanan kadınların bu programın süreçlerinden ve sonuçlarından nasıl etkilendiklerini belirlemek üzere tasarlanan bir araştırma kapsamında, kadınların demografik özellikleri, sosyoekonomik durumları, ne tür işlerle uğraştıkları, kredi kullanımından memnuniyetleri ve gelecek için beklentileri tespit edilerek mikrofinans programının kadın yoksulluğu ve girişimciliği üzerindeki etkileri yorumlanmıştır.

\section{Araştırmanın Kapsamı}

Araştırmanın kapsamı TGMP Antalya Şubesi'nden mikrokredi kullanan kadınlarla sınırlı tutulmuştur. Bu şubeden mikrokredi kullanan 414 kadınla ilgili profil bilgilerinden yararlanılmış, saha çalışmasında bu evreni temsilen 67 kadın ile yüz yüze görüşme yoluyla toplanan veriler kullanılmıştır. Araştırmanın yapıldığı tarih itibariyle TGMP Antalya Şubesi'nin henüz bir yıllık bir geçmişi olması ve bu süre içinde mikrokredi kullanımının kadın yoksulluğu ve girişimciliği üzerindeki etkilerinin henüz yeterli düzeyde ortaya çıkmasının beklenememesi nedeniyle, bulgular ancak Antalya'daki programın kısa geçmişi çerçevesinde yorumlanabilmiş, araştırma sonuçlarının Türkiye çapında genelleştirilmesi mümkün olmamıştır.

\section{Araştırmanın Yöntemi}

$\mathrm{Bu}$ araştırmada nicel ve nitel araştırma yöntemlerinin birlikte kullanılması gerekli görülmüştür. Araştırmacı tarafından geliştirilen soru formunun sahada mikrokredi kullanan kadınlar ile yüz yüze görüşmeler yoluyla uygulanması, kadınların kendi alanlarında gözlemlenmesi ve konunun 
derinlemesine analizini sağlayacak görüşme sorularının uygulanması yoluyla hem nicel hem nitel veriler toplanmıştır. Görüşmeler, TGMP Antalya Şubesi görevlilerinin kredi kullanan kadınlarla yaptığı haftalık alan toplantılarına katılmak suretiyle yapılmıştır. Görüşme sırasında hem soru formu doldurulmuş, hem de görüşme sorularına yanıtlar alınmıştır. Görüşmeler izin alınarak kayıt cihazı ile kaydedilmiş, kayıtlar deşifre edilerek metinler nitel veri olarak kullanılmıştır. Soru formu ile toplanan veriler mikrokredi kullanan kadınların profilini çıkarmayı mümkün kılmıştır.

\section{Araştırmanın Veri Toplama Araçları}

Araştırmanın amaçları, aşağıdaki soru gruplarının kullanılmasını gerekli kılmıştır. Söz konusu gruplar şunlardır:

1. Anket formunun 1. Bölümünde mikrokredi kullanan kadınların profilini çıkarmak üzere hazırlanmış demografik sorulara yer verilmiş, doğum yeri, yaşı, eğitim durumu, medeni durumu, çocuk sayısı ve çocukların eğitim seviyeleri sorulmuştur.

2. Anket formunun 2. bölümünde kadının sosyo-ekonomik durumuyla ilgili sorulara yer verilmiş, ücretli bir işte çalışma durumu, sosyal güvencesi, bakmakla yükümlü olduğu kişiler, hanedeki çalışan kişiler, eşinin işi, ailenin geliri, evin mülkiyet durumu, ailenin beslenme durumu, sağlik durumu, memleketi ve yerleşme nedeni sorulmuştur.

3. Anket formunun 3. bölümünde kadının işi ile ilgili sorulara yer verilmiş, Mikro Sigorta ve Tasarruf Hesabı ile ilgili memnuniyeti, eğitim ve danışmanlık hizmeti isteği, pazarlama desteği isteği, çalışma gün ve saatleri, kredi miktarının yeterliliği, krediyi başka amaçlarla kullanma zorunluluğu, işçi çalıştırma durumu, aile içi ilişkilerin değişim durumu, geri ödeme zorluğu, krediyi kullanma memnuniyeti sorulmuştur.

4. Görüşme soruları konunun derinlemesine analizini sağlayacak şekilde hazırlanmıştır. Kadınlara, mikrofinans programından nasıl haberdar oldukları, kredi almaya neden gerek duydukları, ne işle uğraştıkları, işe nasıl başladıkları, işin ne durumda olduğu, işin hayatlarını nasıl etkilediği, mikrokredi uygulamasının problemleri ve uygulamanın nasıl daha iyi olabileceği sorulmuştur.

\section{Araştırma Örneklemi}

TGMP Antalya şubesinden alınan bilgiye göre, 28.01.2013 tarihi itibarıla, Antalya ilinde mikrokredi kullanan ve bu çalışmanın ana kütlesini oluşturan 414 kadın mevcuttur. $\mathrm{Bu}$ kadınlardan 208'i Antalya Merkez'de, 115'i Alanya'da ve 91'i Manavgat'ta yaşamaktadır. Araştırmanın örneklemi, saha çalışmasının yürütüldüğü 1 Aralık 2012- 30 Ocak 2013 tarihleri arasında TGMP Antalya Şubesi yetkililerinin kadınlarla yaptığı haftalık alan toplantılarına araştırmacının katılması suretiyle erişilen 67 kadından oluşmaktadır. Bu örneklem ana kütlenin $\%$ 16,18'ini oluşturmaktadır.

\section{Araştırmanın Nicel Bulguları}

\section{1. Örneklemin demografik profili}

Örneklemin demografik profili ana kütle profili ile karşılaştırmalı olarak incelendiğinde örneklemin ana kütle profilini tam olarak yansıttığı görülmüştür. Örneklem profili aşağıda özetlenmektedir:

- Doğum yeri dağılımı açısından iki bölgede yoğunlaşma olduğu göze çarpmaktadır. Bunlar Akdeniz $(\% 37,31)$ ve İç Anadolu $(\% 29,85)$ Bölgeleridir. Mikro kredi kullanan kadınların doğum yerlerinin ağırlıklı olarak Antalya, Mersin, İskenderun, Isparta, Hatay, 
Kahramanmaraş, Adana ve Konya, Ankara, Nevşehir, Eskişehir, Kayseri ve Karaman illeri olduğu tespit edilmiştir.

- Yaş dağılımına bakıldığında 41-50 (\%37,31) ve 31-40 (\%34,33) yaş gruplarında yoğunlaşma görülmektedir.

- Örneklemdeki kadınların eğitim durumlarının ilköğretim (\%44,78) ve lise (\%44.78) seviyelerine eşit dağıldığı tespit edilmiştir. Geriye kalan ise yüksek öğretim mezunudur.

- Medeni durum dağılımlarına bakıldığında, \%67,16'sının evli, \%22,39'unun boşanmış, \% 8,96'sının bekar ve \%1,49'unun dul olduğu tespit edilmiştir.

- Örneklemde 1 ila 3 çocuk sahibi olan kadınların toplam oranı \%77,63’tür.

- Örneklemdeki kadınların çocuklarının eğitim seviyeleri \%37,99 ile ilköğretimde yoğunlaşmaktadır. Çocukların \%18,60’1 lise, \%26,36’sı ise üniversite ve üstü seviyelerdedir. Henüz okula gitmeyen çocuk oranı ise $\% 17,05$ 'dir.

- Örneklemdeki kadınların \%16,42'si Antalya doğumludur. Diğerlerinin en yenisi 2 y1l, en eskisi ise 36 yıl önce Antalya'ya yerleşmiştir. Anket sonuçlarına göre, ortalama Antalya'ya yerleşme süresi ortalama 13,18 yıl olarak hesaplanmıştır. Antalya'ya göç etmiş kadınların \% 46,25'inin (31 kadın) Antalya'ya yerleşme nedeni kendilerinin, eşlerinin veya babalarının işleri olmuştur. Bu bulgu ekonomik nedenlerin, ekmek parası kazanma derdinin göçün başlıca nedenlerinden biri olduğunu doğrulamaktadır.

\section{2. Örneklemin sosyo-ekonomik profili}

- Örneklemdeki kadınların \%23,88’i halen ücretli bir işte çalışmaktadır. Bu oranın mikrokredi kullanımından önce \%47,76 olduğu, dolayısıyla daha önce ücretli işte çalışan kadınların yaklaşık yarısının işten ayrıldıktan sonra mikrokrediden yararlanmış olduğu anlaşılmıştır.

- Örneklemdeki kadınların \%17.19'u hiçbir sosyal güvencesi olmadığını beyan etmiştir. Ücretli çalışan kadın oranı \%23,88 olduğuna göre, sosyal güvencesi olduğunu beyan eden \%82,09'un da önemli bir kısmının eşlerinin veya babalarının sigortasından faydalandığı anlaş1mıştır.

- Örneklemdeki kadınların hanelerindeki çalışan ve çalışmayan fertler hesaba katıldığında, çalışan 61 kadının 3 işsiz eşe, 104 çalışmayan çocuğa ve 4 diğer çalışmayan aile ferdinin bakımına katkıda bulunduğu tespit edilmiştir.

- Örneklemdeki evli kadınlar $(\% 67,16)$ açısından bakıldığında, üç işsiz eş hariç, eşlerin \%93,34'ünün gelir sahibi olduğu tespit edilmiştir, ancak kadınların \%32,84'ünün evli olmadığı dikkate alındığında, bu oranda hanede eşin gelir desteği olmadığı anlaşılmaktadır.

- Örneklemdeki 67 hanede toplam 237 kişi, hane başı ortalama 3,54 kişi yaşadığından, 4 kişilik aile için TÜRK-İ̧’in açılkladığı Aralık 2012 açlık (985,00 TL) ve yoksulluk (3.208,48 TL) sınırlarının kullanılması uygun görülmüsştür. Bu sınırlara göre, kadınların yaşadığ1 hanelerin \%35,82'sinin (24 hane) açlık sınırının altında, \%59,70’inin (40 hane) yoksulluk sınırının altında, yalnızca \%4,48'inin (3 kadın) yoksulluk sınırının üstünde yaşadığı tespit edilmiştir. Toplamda örneklemdeki hanelerin \%95,52'nin yoksulluk sınırının altında olduğu anlaşılmıştır.

- Hane gelir aralığı: Gelir aralığı en düşük 400 TL ile en yüksek 4.000 TL arasındadır. Hane ortanca geliri: 1.500 TL'dir. Hane başı ortalama aylık gelir 1739,85 TL olmaktadır. MK'den etkilenen 237 hane bireyinin kişi başı ortalama aylık geliri 491,86 TL'dir.

- Örneklemdeki kadınların \%80,60'ının (54 kadın) kirada oturduğu, sadece \%19,40'1nın (13 kadın) kendi evinde oturduğunu beyan ettiği tespit edilmiştir. Açıkça belirtilmemekle birlikte, kendi evi olduğunu beyan edenlerin evlerinin tapu kaydının eşlerinin veya babalarının üzerinde olduğu tahmin edilebilir. 
- Örneklemdeki kadınlara, her hafta evlerine süt, yumurta, et, sebze, meyve satın alıp alamadıkları sorulduğunda, sadece \%58,20'si (39 kadın) alabildiğini, \%41,80'i (28 kadın) ise alamadığını ifade etmiştir. Sağlıklı beslenme açısından bu besinlerin her gün tüketilmesinin gerekli olduğu ve bu hanelerde çocukların ve gençlerin yaşadığı düşünüldüğünde, bu hanelerde sağlıklı beslenme koşullarının sağlanamadığı anlaşılmıştır.

- Örneklemdeki kadınlar herhangi bir rahatsızlıkları olup olmadığı sorusuna \%41,80 (28 kadın) oranında "evet" yanıtı vermişlerdir. Bu kadar yüksek oranda rahatsızlık belirtilmiş olması da, bu yaş grubu (yoğunluk 31-50 yaş arası) için çok yüksek bulunmuştur. Bu yüksek hastalık oranını, sağlıssız beslenme, yoksulluğun getirdiği zor yaşam şartları, endişeler ve korkular ile ilişkilendirmek doğru olabilir.

\section{3. Örneklemin çalışma koşullarının dağılımı}

- Bulgular kadınların \%11,94'ünün (8 kadın) aldıkları mikrokrediyi bir iş yapmak için kullanmadıkları, özel bazı ihtiyaçlarını karşılamak için kullandıklarını göstermiştir.

- Mikrokredi ile iş yapan 25 kadın (\%37,31) haftada 6-7 gün ve günde 9-12 saat çalıştıklarını beyan etmişlerdir. Bu kadınlar tezgah veya dükkanlarından satış yapmakta ve yaz sezonunda turizm nedeniyle günde 16 saate kadar çalışmaktadırlar. Kışın daha az çalışma olanakları olsa da, bu kez evlerinde satacakları ürünlerin üretimi ile uğraşmaktadırlar. Yani, kadınların önemli bir kısmı yaşamlarını sürdürebilmek için ağır bir iş temposu içinde çalışmaktadır.

\section{4. Örneklemdeki kadınların mikrokredi programı konusundaki görüşleri}

- Araştırmaya katılan kadınlara aldıkları kredi miktarının işlerini kurabilmek için yeterli olup olmadığ 1 sorulduğunda, \%37,30'u (25 kadın) yeterli olduğunu söylerken, \%62,70'i (42 kadın) kredinin yeterli olmadığını, ancak mevcut işlerine veya yeni kurdukları işlerine bir katkı sağladığını belirtmişlerdir. Evde üreten ve satış yapan kadınların çoğunluğu kredi ile malzeme ihtiyaçlarını karşılamışlardır. En büyük giderleri olan malzeme ihtiyaçlarını karşılamalarından dolayı, kredinin yeterli olduğunu düşünmektedirler. Oysa ev dışında faaliyette bulunan kadınların başka giderleri de vardır (Dükkan veya tezgah kirası, enerji, su, iletişim giderleri, muhasebeci ücreti, tabela vergisi, SGK primi gibi). Kredi miktarını yetersiz bulanlar bu gruptaki kadınlardır.

- Kadınların büyük çoğunluğu krediyi yalnızca işleri için kullandıklarını ifade etmiş olsalar da, krediyi kısmen veya tamamen özel ihtiyaçları için kullanan kadınların oranı \%23,88 (16 kadın) olarak bulunmuştur ki bu oran oldukça yüksektir. Bu durumun da yoksulluk nedeniyle ortaya çıktığı söylenebilir. Krediyi iş dışında, ev kirası, gıda, okul araç gereci, çocuk giysisi, odun-kömür alımı, eski ürün borcu ödemesi gibi acil ihtiyaçlar için kullanmışlardır. Bu giderlerin çoğunluğu hanenin temel ihtiyaçları ile ilgili olduğundan kredinin işle ilgili olmayan nedenlerle talep edilmesinin esas kaynağının yoksulluk olduğu doğrulanmaktadır.

- Araştırmaya katılan kadınların \%68,65'i (46 kadın) krediyi geri ödemede zorluk yaşamadığını, \%31,35'i (21 kadın) ise haftalık geri ödemelerde özellikle iki açıdan zorluk yaşadıklarını ifade etmişlerdir. Birincisi, her hafta geri ödenecek meblağ kadar kar elde etme zorunluluğudur. İkincisi, her hafta tahsilatın yapılacağı yere, hangi mesafeden olursa olsun, gelme zorunluluğudur. Örneğin, Alanya ilçesinin büyüklüğü göz önüne alındığında, bu zorunluluk kadınlar için zaman ve para kaybı anlamına gelmektedir. Ayrıca grubun tüm üyelerinin birbirini orada bekleme zorunluluğu da bir zaman kaybıdır. Bu zorunluluğun nedeni ise, ödeme yapmayan bir grup üyesi yerine, diğer grup üyelerinin ödeme yapması kuralıdır. Genelde bu şekilde uygulanan geri ödeme şekli, kadınların üzerinde ciddi bir baskı ve stres yaratmaktadır. Kadın her hafta para kazanmak, geri ödeme için yol parası vermek, zaman 
ayırmak ve ödemeyen grup üyelerinin yerine ödeme yapmak zorundadır. Bu koşullar kredi kullanan kadınları ciddi anlamda zorlamaktadır. Tasarruf hesabı ve mikro sigorta uygulamalarından memnun musunuz sorusuna, kadınların \%94'ü (63 kadın) evet, \%6's1 (4 kadın) hayır yanıtını vermiştir. Derinlemesine görüşmelerde, kadınların bir kısmının bunların ne amaçla uygulandıklarından ve uygulama şartlarından haberdar olmadıkları anlaşılmıştır.

- “Krediyi kullandiğınız için memnun musunuz, başkalarına tavsiye eder misiniz?” sorusunu, kadınların tamamına yakını $(\% 98,50=66$ kadın) evet olarak yanıtlamışlardır. Bu da kredinin kadınların herhangi bir şekilde işine yaradığı şeklinde yorumlanabilir. Mikrokrediyi kullandıktan sonra aile içi ilişkilerinizde nasıl bir değişiklik oldu sorusuna "değişmedi" diyenlerin oranı \%50,80 (34 kadın), "olumlu olarak değişti” diyenlerin oranı \%34,30 (23 kadın) ve "olumsuz olarak değişti" diyenlerin oranı \%14,90 (10 kadın) olmuştur. "Olumlu olarak değişti" diyen kadınlar çocuklarının ihtiyaçlarını karşılayabilmenin, onlara harçlık verebilmenin mutluluğunu çocuklarıyla birlikte yaşadıklarını belirtmişlerdir. Ayrıca, evin bütçesine de katkı sağlamış olmaları, ailenin fertleri tarafından takdirle karşılanmıştır. "Olumsuz olarak değişti” diyen kadınlar, çocuklarının ve eşlerinin, kendilerinin eve fazla zaman ayırmadığından ve ev işlerini ihmal ettiğinden şikâyetçi olduklarını söylemişlerdir.

- Kadınlara işinizle ilgili eğitim ve danışmanlık hizmeti almak ister misiniz diye sorulduğunda, \%53,75'i (36 kadın) evet, \%46,25'i (31 kadın) hayır yanıtı vermişlerdir. Hayır diyenlerin bir kısmı, yaptığı işi her yönüyle çok iyi bildiğini, bu nedenle böyle bir ihtiyaç hissetmediğini ifade etmiştir. Bir kısmının da eğitim ve danışmanlık sözcüklerinin kendileri için ne anlam ifade edebileceğini tam olarak bilememeleri nedeniyle konuya olumsuz yaklaştıkları düşünülmektedir.

- Kadınlara pazarlama sorunlarınızı çözmek için destek ister misiniz diye sorulduğunda, $\% 53,75$ 'i (36 kadın) hayır cevabı vermiştir. Bu yüksek oran yine, kendileri için aslında anahtar bir sözcük olan pazarlama sözcügünün tam olarak anlaşılmamış olduğu şeklinde yorumlanabilir.

\section{Araştırmanın Nitel Bulguları}

Saha araştırmasında yüz yüze görüşmelerde toplanan nitel verilerden elde edilen bulgular, ziyaret süresince araştırmacı tarafından alınan gözlem notlarına ve yapılan görüşmelerin tematik analizine dayandırılmıştır.

\section{Mikrokrediden Haberdar Olma Kaynakları}

Kadınların büyük çoğunluğunun $(\% 76,14)$ mikro krediden arkadaş, akraba, komşu gibi yakın çevrelerinden haberdar oldukları anlaşılmıştır. Kadınların bu soruya yanıtları şöyledir:

"Ben derneğin merdivenini yıkıyordum. O zaman da TGMP şubesinden yetkililer gelmişti. Merdiveni ylkarken, 'böyle böyle, sen de al' dediler. Belki ödeyemem, belki zor durumda kalırım diye tereddütte kaldım. Almamıştım. Ondan sonra ikinci aşamada, arkadaş 'haftalı ödersin' dedi. Ben merdiveni 10 TL'ye ylkıyordum. Bir de evin kirasl yüklenince, ben de mecbur kaldım, aldım".

"Arkadaşım haber verdi. H. Hanım ve kaymakam bir toplantı yaptılar. Beş kişi bayan olacak, ondan sonra alacaksını diye. Orada içimden geldiği gibi konuştum. Ben tek kişiyim, beş kişiyi nasıl bulayım? O arada arkadaşlar bana teklifte bulundu, bizimle ol diye. Onlar aldllar beni yanlarina".

"Sezonluk çalıştı̆̆ımız için kışın evde boşuz. Çok sıkıştım, evde de bir 
şeyler yapabilmek, örebilmek için yani, belli bir para gerekiyordu. Kadın ve dul olduğun için, hiç kimse seni istemiyor. İnternete girerek bayanlara kimlerin para verebileceğini araştırdım. Mikro krediyi gördüm ve şubeye telefon açtım. H. Hanım, 'oradan 20-25 kişi toplayabilirsen gelirim size kredi verebilirim' dedi” .

"Teyzemin kızından. Teyzemin kızı da çünkü aynı işi yapıyor. Mikro kredi dağıtıyor o da. O da Erzurum'da. O bana bahsetti. 'Abla AVON yapıyorsun, neden almıyorsun dedi. Beş kişilik grup oluştur, kredi verebilirim, dedi' "'.

Bu bulgulardan bilginin en kolay bilgi dağıtım şekli olan, ağızdan ağıza haberleşmeyle yayıldığ anlaşılmaktadır. Evde oturan kadınlar en kolay ulaşabilecekleri ve irtibat halinde oldukları kişilere, yani arkadaş, akraba ve komşularına ulaşmışlardır. Grupların da bu şekilde daha kolay oluştuğu anlaşılmaktadır.

\section{Mikrokrediye Gerek Duyma Nedenleri}

Kadınların büyük çoğunluğu $(\% 77,61)$ mikrokrediden yararlanmaya mevcut işleri veya yeni kuracakları işleri için gerek duyduklarını açıklamışlardır. Yoksulluk nedeniyle, kendilerinin veya yakınlarının birikmiş bir sermayesi ve bankadan kredi alabilmek için de gösterebilecekleri bir teminatları olmadığı için mikrokredi programı tek çareleri olmuştur.

Kadınların bu soruya yanıtları şöyledir:

"Yaptığım çalışmalara katkısı olsun diyerekten. Malzeme almak için. Çiçek çalışması yapmaya başladım. Alanya'ya özgü koza çiçeği, o da masrafli. İpek kozasından koza çiçeği. Bunu çok geliştirmek ve ilerletmek istiyorum. Kursuna gittim. Alanya Belediyesinin düzenlemiş olduğu ilk kursiyerlerdenim. Şimdi de inşallah ekmeğini yiyecem. Satış imkanı yaratmaya çalışlyorum. Çevreye bu şekilde tanıtım yapıyorum, şeffaf kutular içersinde renkli çiçeklerle. Kısmet olursa kart falan bastıracam. İşte şahıslara, çiçekçilere, yani elimden geldiği kadar kendi çapımda duyuru yapıp sipariş almaya çalışıyorum. B. Çiçekçilikten ilk siparişimi aldım, ilk satışımı yaptım. 3 dal çalıştım, 2 'sinin çiçeği daha çok. 3 dalın 80 TL'ye satışını yaptım. Beyazı, sarısı, her rengi var, çok zevkle yapıyorum. Bana da kazanç sağladı̆̆ için, çok mutluyum yani” .

"Dlşarıya zaten el örgüsü yapıyordum. O gelen para bana çok destek oldu. 700 TL bana 700.000 TL gibi geldi. Malzeme aldım. O arada odunum yoktu, ne yalan söyleyeyim, odun da aldım o parayla. Inkar edemem yani”.

"İsimizi ilerletmek için. Yaptığım işe katkı sağlamak, ürünleri çoğaltmak, elimde ürün tutmak için”.

"Ev hanımıyım, evde bir şeyler üretip satmak ve eşime de destek olmak için, eve katkr için".

Kadınların bir bölümü $(\% 11,94)$ krediyi özel ihtiyaçları için kullandıklarını ifade etmiş olsalar da, kadınların yaşam koşulları dikkate alındığında, bu oranın aslında daha yüksek olabileceği tahmin edilmektedir. Örneklemdeki kadınların bazıları diğer bazı kadınların aldıkları kredinin tamamını eşlerine verdiklerini veya birikmiş fatura ve kira borçlarını ödediklerini ifade etmişlerdir. Gözlemler de bu ifadeleri doğrular nitelikte olmuştur. 


\section{Mikrokredi İle Yapılan İşin Niteliği}

Sayısal veriler, 25 kadının $(\% 37,31)$ evden satış, 31 kadının $(\% 46,27)$ ev dışından satış yaptıklarını, diğer 3 kadının $(\% 4,48)$ kendilerinin de çalıştıkları eşlerinin dükkanlarına katkı sağlamak amacıyla bu krediyi kullanmış olduğunu ve 8 kadının $(\% 11,94)$ aldığ mikrokrediyi özel ihtiyaçları için kullandığını; kadınların \%43,29'unun (29 kadın) kendi ürettikleri ürünleri, \%37,31'inin (25 kadın) ise hazır ürünler sattıklarını göstermiştir. Bu konuyla ilgili görüşmede anlatılanlar şöyledir:

"Belediyenin temin ettiği takı standını açıyorum. Kendim takı tasarliyorum, sattyorum. Bir de ipek böceği kozasindan çiçekler üretiyorum. Belediye Ipek Eller diye bir proje hazırlad, hani eski sanatları canlandlrıp, hanımlara iş kaynağı olsun diye belediye kurs açtı. Kurslara gidiliyor, belediye kurslara gidenlere kendisi de sipariş veriyor. Ruhsat almaya gelen her şeye, müşterisine, bir nevi plaket gibi veriyor. Ben onlar şeyde değerlendiriyorum, takllara monte ediyorum".

"Lokanta, ev yemekleri üzerine. Evde yaptığımız tarzda, öyle çok sanayi tipi değil. Evde kullandiğım ölçülerde, tencerelerde. Öğrenci kapasitem var, üniversiteden onlar geliyor. Yazın turizm biraz destek oluyor. Ayakta kalmaya çalışlyoruz".

"Ben şimdi şöyle, kış döneminde kuşlık, mesela organik yiyeceklerden memleketten getirtecem şimdi, haftaya kayınbabam gelecek. $100 \mathrm{~kg} \mathrm{ba-}$ dem getirecek, orda beşe alsam, burada on beşe satacă̆ım, o şekil. Yaprak falan, oradan allyorsun, burada iki katına. Pekmez, badem, kuru üzüm, çünkü kendi bahçemiz de var orda. Yazın da mesela sebze, meyve türü, kiraz bahçemiz var, amcam orda. Kargo parası vermeden, buraya gelenlerle. Pazarda veya komşulara satacam. Çünkü ben sipariş allyorum, kim ne kadar istiyorsa. Kayınbabamı da pazara koyucam. Arkadaşım var, onlarla pazarlık yaptı, onun pazardaki tezgahinda olucam ben. Onların tezgahına koyuyoruz, çünkü çok yer kaplamıyor zaten".

"Evde kazak, hırka, lif örüyorum. Kışın bunları satarak, geçimimi să̆lıyorum. Pazardaki arkadaşın tezgahına veriyorum. Evlerde satıyorum”. "Oyalar yapıyorum, yazmanın kenarlarını oyalıyorum, kasnak işi yaptyorum. Bunları arkadaşın yerine birakıp, satabiliyorum. Müşteriyi daha çabuk kazaniyorum böyle. O zaman da bunlara daha çok malzeme alıp, malzeme almak için, böyle bir şeye kalklştık. İşimize yarad, çok güzel kazandlk".

$\mathrm{Bu}$ bulgular genel olarak değerlendirildiğinde, kadınların ya fazla bir bilgi birikimi ve eğitim gerektirmeyen ve birbirine benzer geleneksel el emeği - göz nuru işlerle uğraştıkları, ya da hazır ürünler sattıkları anlaşılmaktadır. Bu nitelikleriyle yapılan işlerin iyi bir kazanç potansiyeli bulunmadığı, kıt kanaat denilebilecek seviyelerde çalışıldığg anlaşılmaktadır.

\section{Yapılan İşe Nasıl Başlandığı}

Bulguların, kadınların büyük çoğunluğunun $(\% 73,14)$ satış için hazır ürünler veya üretim için malzemeler satın alarak işe başladıklarını göstermiştir. Kadınların bu soruya yanıtları şöyledir:

"O küçük rakam bile benim çok işimi gördü. İstanbul'da daha çok çeşit bulabildim. Hem de buraya göre oranın fiyatları çok daha uygun. Eminönü, Tahtakale ucuz yerler. Şimdi bir takı tezgahım var. Ürettiğim 
malzemeleri orada sergiliyorum, çok ilgi çekiyor. Malzemelerimi sürekli yeniliyorum, yani tezgahda ışıl ışıl şeyler. Sürekli bir tezgah, yaz sezonu boyunca. Otellerin çok olduğu, turistlerin çok rahatlıkla dolaştığı bir cadde. Belediyenin bize tahsis ettiği bir bölüm var, tezgahım orada. Ücret almuyorlar, vergi almiyorlar, kendi ürettiğimiz malzemeler olduğu için. Malzemenin ötesindeki şey, yani emeği falan düşünmezseniz, malzeme maliyetini düş̧üğünüzde, gerisi kar olarak bize geri dönüyor. Çok memnunuz".

"Gittim ip aldım, tülbent yapmak için tülbent aldım. Hem dışarda çalıştım, gece geldim, o elişlerini yaptım. İzinli günlerimde yaptım. Tülbent kenarı oya yapıyorum".

"Simit dolabı aldık, onu çalıştırlyoruz marketin içinde. Fırıncıyla anlaştık, iyi gidiyor şu an. Mikrokrediyi alınca, bunu ben kendim düşündüm. Kar da zarar da benim olsun dedim. Daha da ilerletmeyi düşünüyorum. Çok da güzel oldu yani. Belirli miktarda bize simit geliyor artık. Çeşitlendiriyoruz. Takip ettik, bugün ne kadar gidiyor, hafta sonu ne kadar gidiyor. Bazı şeyleri araştırmamız gerekiyor”.

"Evde kazak, hırka, lif örüyorum. Kışın bunları satarak geçimimi să̆lıyorum. Pazardaki arkadaşın tezgahına veriyorum. Evlerde satıyorum”. "Parayı aldıktan sonra, toptancı buldum. İç çamaşırı ve tuhafiye için her şeyi olan. Parayl verdim, bir poşet mal oldu. Birisi demir verdi, birisi çadırımı dikti, MASİAD'ın aracılı̆̆ ile yardım eden insanlar bulundu ve tezgahım kuruldu. Çamaşır, tuhafiye, hediyelik eşya var".

$\mathrm{Bu}$ bulgular kadınların işe başlarken bir iş fikirleri olduğunu, altından kalkabilecekleri bir iş alanı seçtiklerini göstermektedir. Ancak görüşmeler ve gözlemler seçtikleri işi büyütmek için bilinçli bir plan ve programları olmadığı izlenimi doğurmuştur.

\section{Kurulan İşin Durumu}

Sayısal veriler işlerinden memnun olan kadınların oranının \%38,80 (26 kadın), 'İdare ediyor' diyen kadınların oranının \%29,85 (20 kadın) ve işlerinin iyi gitmediğini belirten kadınların oranının \%28,36 (19 kadın) olduğu göstermiştir. Bu konuda sorulan soruya verilen yanıtlar şöyledir:

“Allaha şükür, gene günlük 30-35 TL'yi buluyor. Allah bereket versin”.

"O kadar da çok güzel değil yani, damliyor. İyiye gidiyor gibi ama yetersiz. Tezgah açıp, vergi ödeyemem. Tezgahı olan arkadaşların çoğu vergiden borçlu. Gece gündüz uğraşıyorum, fakat 10 TL'lik bir şeyi ancak 5 TL'ye satabiliyorum. Kar çok az ve tüm bayanlar elişi yaptı̆̆ için rekabet çok fazla. Bu iş çok yorucu".

"Ek işle gidiyor, sadece burayla mümkün değil. Sezonda otelde kuaförde çalışıyorum. Sezon bittikten sonra tezgahı devam ettiriyoruz”.

"Şu an kötü durumdayım. Işsim çok çok iyiydi. Ben de bu ara devretmek zorunda kaldım, yani devredeceğim. Valla mal alamıyorum, sıkıştım.

Ikinci bir krediyi almama rağmen, o bana yetmedi”.

Bu kadınlar içinde işlerinin durumunu 'iyi değil' veya 'kötü' diye ifade eden yaklaşı \% 30 'luk dilimdekiler işlerinin iyi gitmediğini, işyerlerini kapatmak zorunda kaldıklarını, üstelik borçlandıklarını ifade etmişlerdir. Bir kısmı ise krediyi özel ihtiyaçlarını karşılamak için aldıklarını 
itiraf etmişlerdir.

\section{Mikrokredi Kullanımının Hayatlar Üzerindeki Etkisi}

Görüşmenin altıncı sorusuna alınan yanıtlara göre, mikro kredi kullanımının kadınların hayatları üzerindeki etkisinin olumlu mu, yoksa olumsuz mu olduğu aşağıda özetlenmiştir:

Hayatlarının olumsuz etkilendiğini söyleyen kadınların $(\% 19,40)$ özetle söyledikleri şöyledir:

"Çok çalışıyorum, yoruluyorum, sosyal hayatım kalmadl, çocuklarla görüssemiyorum, borçlandım, özel hayatım kalmadı, sağlığım bozuldu, işi yürütemedim".

Krediyi yeni alan 2 kadın görüş bildirmemiştir. Hayatlarının olumlu etkilendiğini söyleyen kadınlar ise $(\% 77,61)$ özetle, "Kimsenin eline bakmıyorum, kendime güvenim geldi, üretken ve yaratıcı oldum, çocuklarımın ihtiyaçlarını alabiliyorum, çocuklarımın harçlıklarını verebiliyorum, psikolojik olarak rahatlyyorum, çevrem oldu, arkadaşlarım oldu, dostlarım oldu, devamlı müşterilerim oldu, artık evde sıkılmıyorum, manevi olarak iyi geldi, kadınlar arası dayanısma oldu, maddi yönü güzel, başkasına muhtaç değilim, meşgul oluyorum, sinir, stres azaldl, sosyalleştim, çevrem değişti, stres atıyorum, yalnızca kendime sorumluyum, moralim yükseldi, să̆lığım düzeldi, özgüvenim arttı, içimdeki cevher dışarı çıktı, boş durmuyorum, eşime bağımlı değilim, mutluyum, borçlarım azald, kendimi kendime ispat ediyorum" anlamına gelen yanıtlar vermişlerdir.

Tek tek ele alındığında, kadınların bu soruya yanıtları şöyledir:

“Psikolojik olarak çok rahatllyorum ben. Illk önce zaten önemli olan o değil mi?”

"İ̧si seviyorum, bir şeyler üretmeyi. Yaratıcıllı̆ seviyorum, farklı şeyler ortaya çıkarmayl. Bir de güzel bir çevre oluştu. Mikro kredide burada bir sürü arkadaşla karşılaştım. Dostluklar kuruluyor. Bir de devamlı müşterilerim olmaya başladi. Alanya'ya her sene arka arkaya gelen turistler var, gelip beni buluyorlar. Demek ki ürünler hoşuna gitmiş, benimle sohbet hoşlarına gitmiş. Alanya'dan da böyle müsterilerim var. Gelip de benimle sohbet eden, arkadaş olanlar. Böyle bir kazancı da oluyor bu işin".

"Bu işi kurmam benim için gerçekten çok önemliydi, çünkü her şeyden önce paylaşım. Benim kurduğum bu işle birlikte birkaç arkadaşın daha emeğini pazarlama imkanı oldu. Bu çok güzel bir bakış açısı dünyaya. Dayanışma, çok minicik de olsa. Birbirimizden haberdarız. Bu bile çok önemli, kim ne yaplyor? Kimin elinden hangi iş geliyor? En azından, en küçük bir haberleşmeyle, arkadaşımın ürettiği bir şey ya da başka bir arkadaşımın kutuları, diğerinin örgüleri, anında koordinasyonu kurabiliyoruz. Yeter ki gerçek anlamda değerlenecek tasarımla pazara ulaşabilmek. Bunun için de duyurulmamız, tanıtım lazım".

"Özgüveniniz artıyor el becerileriniz geliştikçe. Özgüveniniz arttıkça, etrafa bakışınız daha farklı oluyor. Sosyal yaşantınız biraz değişiyor, daha güzel baklyorsunuz. İçinizdeki cevherleri dışarı çıkartıyorsunuz, üretiyorsunuz, bir şeyler üretmiş olmanın hazzını yaşıyorsunuz".

"Evime, çocuklarıma az zaman ayırabiliyorum, ama çalışmak güzel. En azından kendimi kendime ispat edebiliyorum. Boş durmuyorum. Haftanın 
yedi günü burdayız, erken açıp geç kapatıyoruz”.

Kadınların bir kısmının aldıkları krediler ile küçük işler yapmaya başlamış olmalarının yanı sıra, büyük çoğunluğunun manevi anlamda olumlu etkilendiği anlaşılmaktadır. Hayatlarında belki de ilk kez bağımsız olarak bir yola çıkmış, tek başına bir sorumluluk üstlenerek kendini kanıtlama fırsatını yakalamışlardır.

\section{Mikrokredi Uygulamasının Problemleri}

Örneklemdeki kadınlara mikrokredi programının uygulamasında yaşadıkları zorluklar sorulduğunda, aşağıda ifade edilen problemler dile getirilmiştir:

"Haftalık maddi problem yaşıyoruz aslında. Elimize para geçecek mi, geçmeyecek mi? Şu anda Manavgat'ta sezon da bitiyor, çünkü turizme yönelik bir yer".

"Burada bir şube olsa, günü belli olsa iyi olur. Arkadaşlar çok zorlaniyorlar. Hava şartlarına göre, birbirimizi beklemekten burada 4 saat geçiriyoruz".

"Verdikleri para çok az. Bir de parayı alıyorsunuz, iş yapıyorsunuz ama bunu satamıyorsunuz. Yani hemen paraya döndürebilme imkan yoksa her hafta bu parayl ödemek daha zor. Bayanlar bir şeyler üretiyor ama bunu paraya çevirmek önemli. Paraya çevireceksin ki ödemesini yapabilesin".

"Benim tek şeyim, aslında çok güzel. Kadınların kullanması destekleniyor. Bunun araştırarak yapılmast, yani herkese değil de, nasil söyleyeyim, ödeyebilecek ve bu parayı nerelerde değerlendirebilecek, bunu araştırıp da, tayin edilip ailelere, hanımlara verilmesi. Çoğu, açıkçası gördüğ̈̈m kadartyla, parayı götürüp, kocasına veren oldu. Kocası da onu kahve köşelerinde yedi ve kadınlar temizlik yaparak şimdi ödemeye çalışlyorlar".

"Bir kişi ödemeyince diğer kişilerin ödemesi biraz zor oluyor. Bir de ben merkez olunca bayă̆ı zor oluyor. Yabancı kişi girince iş daha karışıyor. Ama aileden bir kişi olunca ödersin".

"Alanya çok geniş bir bölge olduğu için uzaktakiler zorlanıyor. Hiç geliri olmayan bir kişi için 4 TL yol masrafi çok. Bazı arkadaşlar para ve defterlerini diğer arkadaşlara veriyor, onlar sağ olsun getiriyor”.

Mikrokredi uygulamasının problemleri incelendiğinde, kadınların yaklaşık \%59'unun kredinin haftalık geri ödenme zorunluluğundan şikayetçi olduğu, bir bölümünün de kredi meblağını düşük buldukları görülmüştür. $\mathrm{Bu}$ projenin prensiplerinin gereği olarak, 5 kişilik mikrokredi gruplarının üyelerinin her hafta bir grup üyesinin evinde başkanları ile birlikte toplanması, bu toplantıya merkez başkanı ve şube yetkilisinin de katılması, genel anlamda bilgi alış verişinde bulunulması, herkesin birbiri ile görüşerek varsa sorunlarını konuşması, çözümler bulunması ve haftalık tahsilatların yapılması öngörülmüştür. Kadınlar haftada bir gün büyük bir toplantı salonuna (Ticaret Odası, Valilik, Kaymakamlık gibi) ödeme yapmak üzere gelmek zorundadırlar. Ancak uygulamada, toplantıya gelen kadınların yalnızca para ödemesi yaptıkları, farklı bir diyalog oluşmadığı gözlemlenmiştir. Genellikle gruptan bir veya birkaç kadın gelerek diğer kadınların parasını getirmektedir. Dolayısıyla, yüz yüze görüşme imkanı çok kısıtlıdır. Kadınların yaklaşık yarısının bu toplantılara katılamadığı da gözlemlenmiştir. Yalnızca ödeme yapmak için gelmek, yukarıda bahsedilen sebeplerden dolayı külfetli ve zahmetli olduğundan, kadınlar 
bu yolu bulmuşlardır.

Diğer bir sorun ise kredi miktarları ile ilgilidir. Daha önce 700 TL ve şimdi 1.000 TL olan ilk kredi miktarı evde üretim yapan kadınlar açısından yeterli olabilse de, bir işyeri açma hedefi olan kadınlar için çok yetersizdir. Bazı kadınlar, yapılacak işe göre kredi miktarının ayarlanmasını, diğer bazıları, ilçelerin yetkili makamlarının kapalı mekanlarda ücretsiz veya düşük bir ücret karşılığında sürekli satış yerleri tahsis etmelerini önermişlerdir. Mevcut açık pazarlarda, kadınlar mevsimsel hava şartlarına maruz kalmaktadırlar. Hava şartları nedeniyle müşteri kaybı yaşanmaktadır. Oysa kapalı bir mekanda bu sorunlar olmayacak, kadın her gün dükkanına gider gibi standının başına gidebilecektir.

\section{Uygulamayı Daha Etkili Hale Getirecek Öneriler}

Görüşme yapılan kadınların yukarıda belirtilen sorunlarla ilgili önerileri aşağıdaki sözlerle ifade edilmiştir:

"Haftalı ödeme zor oluyor. Ayllk olsa ya da bir banka numarası olsa oraya yatırsak. $O$ daha güzel olur. Bir hesap açılır, bize derler, gidin yatırın. O zaman haftalıkda olur. Ama her hafta buraya gelip beklemek zor".

"Bize daha önceden söz verdiler. Bize sürekli bir dükkan şeklinde, bir pasaj gibi bir yer yapılacaktı. Öyle olsa gider dükkanda işimizi yaparız. Şimdilik bekliyoruz. Ücretsiz olmasa bile, cüzi bir miktar alsınlar. Kadınlara destek verilsin, erkekleri geçerler".

"Insanların yaptıkları işe göre limitleri farklılaştırabilirler bence. Boncuk yapanla, örgü örenle ayn olmuyor. Onlar evde yapıyor, vergisi yok, şeyi yok. Vergi kaydım var, oda kaydım var".

"Bir güzel mikrokredi köyü, belki çok abartılı gelebilir. Bir mikrokredi mahallesi, bir sokağ olabilir. Herkes yaptıklarını orda sergileyebilir. Belediyenin verdiği bir sokak var, Toplum Merkezinin verdiği bir yer var. Bunlar ücretsiz”.

"Bunun haftalı ödeme değil de aylık ödeme olursa 15 güne de razıyız. Genel olarak bu bayanlar için bir şikayet. Meblağı daha yüksek tutsalar. Ve bu bizim yaptıklarımız, bu mikro kredi alan bayanlar evlerinde bir şeyler yapmak için uğraşıyor, farklılık yaratmak istiyorlar. Bunlar için bir yer açmak istiyoruz, sergilemek istiyoruz".

"Ben bir mikrokredi alıcısıyım. Sikışıksam bana destek olmaları gerekir. Benim işimi kaybetmemem gerekiyor diye düşünüyorum. Ama ben böyle bir desteği görmüyorum. O zaman bana bunun ciddi bir anlamda faydast yok. Şu anda ben bunu yaşlyorum. Ben onlardan da rica ettim, 'bana biraz miktarı düşük tutun' dedim, ben bu işimi kaybetmeyim. Ama hiç ilgilenen yok, ne arayan ne soran. Ama buraya reklam amaçl çok gelip gittiler. Bir sürü resimler çekildi, şudur, budur".

"Akraba olsa zor değil. Mesela yaparsin, ablan olur. Evliysen kayınvaliden görümcen olur. Onlardan toplarsin. Ama mesela diyelim, benim ablam ödemedi, ben ondan her halukarda alırım, çünkü ömür boyu ти konuşmayacaksin. Ama yabanci, telefonunu kapatsa, bulamazsın".

"Tek kişi alabilse daha iyi olur. Bir kişi artı iki kefil de olabilir".

"İ̧s kuracak kişiler için değişik sistemler olabilir".

“Ödeme banka ile, kredi kişiye özel olsun”. 
"Haftada değil de bana göre, yani aylık olsa daha güzel olurdu. İnsan ona göre aylık kazancından, bu kredi için diyebilirim. Haftalık bir anda. Para daha da fazla olsa, daha büyük işler yapabiliriz".

"Daha fazla para bize verebilirlerdi. 750-1.000 TL hiçbir şeye yetmiyor. Haftada 20 TL ödenmesi çok fazla, çünkü bankadan aynı paraya daha az ödüyorsun”.

Mevcut uygulamada, kadının bilinçsiz bir şekilde ve mecburiyetten, yani yoksulluktan kurtuluş amacıyla bir kredi kullandığı anlaşılmaktadır. Kadınların en büyük sorunu ve stresi, kredinin haftalık geri ödemesini ne şekilde yapabileceğidir. Şube yetkililerinin de en büyük sorunu ve stresi, haftalık kredi ödemelerini noksansız tahsil edip aynı gün bankaya yatırmaktır. Yani, kadınların da personelin de odaklandıkları tek konu ödemeler olmaktadır.

\section{Sonuçlar ve Bir İşbirliği Modeli Önerisi}

Bu çalışmada kadın yoksulluğu ve kadın girişimciliği ile ilgili literatür incelenerek dünyada ve Türkiye'de kadın girişimciliğini geliştirmeye ve kadın yoksulluğunu azaltmaya yönelik programlar ve bunları yürüten kurum ve kuruluşlar özetlenmiş, ayrıca Antalya'da yürütülen Türkiye Grameen Mikrofinans Programı (TGMP) çerçevesinde dağıtılan mikrokredilerden yararlanan kadınlar üzerine yürütülen bir saha çalışmasının bulguları raporlanmıştır. Antalya'da mikrokredi programından yararlanan kadınlarla yürütülen görüşme ve anket çalışmasından elde edilen sonuçlar şöyle özetlenebilir:

- Örneklemin profili: Araştırmanın saha çalışmasında ulaşılabilen 67 kadının büyük çoğunluğunun ana kütle ile uyumlu olarak doğum yerleri Akdeniz Bölgesinin illeri ve İç Anadolu Bölgesidir; yaş aralığı 20 ile 50 arasında değişmektedir; eğitim durumları ilköğretim ve lise seviyelerine eşit dağılmaktadır; çoğunun medeni durumu evlidir, çocuk sayıları 1 ile 3 arasında, çocuklarının eğitim seviyeleri okul öncesi ile lise arasında değişmektedir ve Antalya TGMP şubesine katılım tarihleri 2012 yılıdır.

- Örneklemin sosyo-ekonomik durumu: Araştırmanın sosyo-ekonomik verileri, örneklemi oluşturan kadınların büyük çoğunluğunun aileleri ile birlikte açlık sınırı ile yoksulluk sınırı arasında yaşamakta olduğunu, mikrokrediyi ailenin gelirini arttırmak için bir iş yapmak üzere kullandığını, evinin kira olduğunu, temel gıda maddelerini almakta zorlandığını, sağlık sorunları bulunduğunu ve Antalya'ya ailesinin işi nedeniyle göç etmiş olduğunu göstermiştir. Kadınların büyük çoğunluğunun sosyal güvencesi vardır, eşleri ücretli veya esnaf olarak çalışmaktadır ve hanelerinin aylık geliri 500 ile 2.000 TL arasında değişmektedir. Kadınların bir kısmı ayrıca ücretli bir işte de çalışmaktadır.

- Örneklemin iş ile ilgili durum bulguları: Örneklemi oluşturan kadınların büyük çoğunluğu haftada 6 veya 7 gün, 5 ile 12 saat arasında çalışmaktadır, TGMP'den arkadaşları, akrabaları ve komşuları vasıtasıyla haberdar olmuşlardır, krediyi almaya malzeme ve ürün alımı nedenleriyle gerek duymuşlardır, büyük çoğunluğu evde el örgüsü, takı vb. hediyelik eşya üretmekte veya eşarp, şal, iç çamaşırı, kozmetik gibi hazır ürünler satmaktadır, bazı kadınlar da sipariş üzerine evden dantel, piko, oya, ipek kozasından koza çiçeği, ipek kozasından bürümcük dokuma veya ev yemekleri yapıp satmakta veya kendi dükkanında takı, ev yemekleri, tuhafiye, iç giyim veya market ürünleri satmaktadır. Birkaç kadın kuaför ve güzellik bakım hizmetleri vermektedir. Örneklemi oluşturan kadınların büyük çoğunluğu malzeme satın alarak veya hazır ürün satın alarak işe başlamıştır ve çoğunluğu işlerinin durumunu iyi veya orta olarak değerlendirmiş; bir bölümü mikrokredi kullanımının hayatlarını olumlu etkilediğini belirtirken bir bölümü aile içinde bazı olumsuz etkilerden söz etmiş, bir bölümü ise ailenin bu işten pek etkilenmediğini belirtmiştir. 
Bu araştırmanın bulguları Antalya'da yürütülen TGMP ile sınırlıdır. Çalışmanın yürütüldüğü dönemde bu programın henüz bir yıllık bir geçmişi olması, araştırma sorusunun yanıtlanması konusunda önemli bir kısıt teşkil etmektedir. Alanyazında kadının bu krediler aracılı̆̆ıyla yoksulluktan kurtulması için en az 5-10 yıl gerektiği belirtilmektedir. Bu nedenle bu çalışmanın bulgularının henüz bir yıllık bir mikrofinans programıla ve Antalya'nın sosyo-ekonomik bağlamı ile kısıtlı olduğu vurgulanmalıdır. Bu kısıtların üstesinden gelebilmek için Türkiye'nin farklı bölgelerinden ve geçmişi daha eski olan mikrofinans programlarıyla benzer çalışmaların yürütülmesi önerilebilir.

Mevcut araştırmanın bulguları Antalya TGMP çerçevesinde mikrokrediden yararlandırılan kadınların henüz hanelerini açlık veya yoksulluk sınırı üzerine çıkaracak bir gelire sahip olamadıklarını; mikrofinans programının, bir yıllık geçmişi süresince bu kadınların çoğunluğu üzerinde girişimciliği geliştirecek ve yoksulluğu ortadan kaldıracak seviyede bir etki yaratamadığını ortaya koymuştur. Nitekim Balkız ve Öztürk (2013) tarafından Diyarbakır'da yürütülen benzer bir araştırmanın sonuçları da mikrokredi ile yapılan işten elde edilen kazancın düşüklüğünün kadının ekonomik bakımdan güçlenmesine yetmediğini tespit etmiştir. Mevcut çalışmanın saha araştırmasında yapılan gözlemler ve görüşmeler mikrokrediden yararlanan kadınların, sürekliliği olan ve tatminkar gelir sağlayabilecek bir iş kurabilmeleri için finansal destek dışında başka desteklere de ihtiyaç duyduklarını ortaya koymuştur. Bu çalışmanın nitel bulgularında görüleceği gibi, çoğunluğu evde el emeğine dayalı üretim yapmakta olan kadınların ürünlerini sergileyerek potansiyel müşterilerle buluşabilecekleri, açık pazarlar dışında, kalıcı satış yerlerine ihtiyaçları bulunmakta; yaklaşık yarısı eğitim, danışmanlık ve pazarlama desteğine ihtiyacı olduğunu belirtmekte; \%62,70'i kredinin yeterli olmadığını düşünmektedir. Problemlere bu detayda yaklaşıldığında, bunların zaman içinde kadınların kendi başlarına çözebilecekleri nitelikte olmadığı, yapısal olarak kalıcı nitelik taşıdığı ve literatürde sonuç almak için gerekli süre olarak belirtilen 5-10 yıl geçse bile, kadınların yoksulluk ve güçsüzlük görünümünün çok fazla değişemeyeceği sonucuna varılmıştır.

Yukarıda da belirtildiği gibi, ilgili literatür mikrofinans programlarının etkileri ile ilgili farklı sonuçlar sergilemektedir. Örneğin Littlefield et al. (2003) çalışması kadınlara sağlanan mikrofinansın hane halklarının acil ihtiyaçlarına yanıt verdiğini, sağlık ve eğitime yatırım yapıldığını ve çeşitli nakit ihtiyaçlarına çözüm getirdiğini ileri sürmektedir. Mevcut araştırmanın bulguları bu makalenin bulgularını doğrulayabilecek bir zaman perspektifine sahip değildir, ancak kadınların görüşmelerde çocuklarının günlük ihtiyaçlarını karşılamada rahatlık kazandıklarını belirtmiş olmaları bu doğrultuda olumlu bir gelişme yaşandığına işaret etmektedir. Grameen Bankasının kurucusu ve mikrofinans kavramının yaratıcısı Profesör Muhammed Yunus Economist dergisine 2009 yılında verdiği demeçte, her y1l Grameen Bank müşterilerinin \%5'inin yoksulluktan kurtulduğunu ileri sürmüştür. $\mathrm{Bu}$ oranın anlamlı seviyede yüksek sayılamayacağı açıktır. Aynı yıl yayımlanan bir başka çalışmada ise Chowdhury (2009) mikrofinans programlarının evrensel bir yoksullukla mücadele aracı olarak etkinliği üzerine yürütülen tartışmalar üzerine eleştirel bir değerlendirme yapmıştır. Yazar, mikrofinansın bazı yenilikçi yönetim ve işletme stratejileri geliştirmiş olmakla birlikte, yoksulluğun azaltılması üzerindeki etkisinin kuşkulu kaldığını ileri sürmekte, ancak, mikrofinansın bir güvenlik ağı oluşturmak ve tüketimi düzenlemek konusunda önemli bir rol oynadığını vurgulamaktadır. Yazara göre, mikrokredi kullanıcıları muhtemelen yaparak öğrenmeden ve öz saygının artışından da fayda sağlamaktadır. Bununla birlikte yoksulluk üzerinde dikkate değer bir etki yaratmak için kamu politikalarının büyümeye ve sermaye artırıcı programlara, geniş çapta üretken istihdam yaratmaya odaklanması tavsiye edilmektedir. 
Bu tartışmalar mikrokredi programlarının yoksulların yaşam şartları üzerinde bazı hafifletici etkiler yaratmakla birlikte henüz yoksullukla mücadelede tek başlarına etkilerinin doğrulanmış olmadığını göstermektedir. Bu çalışmanın sağladığı ipuçlarına dayanılarak mikrofinans programlarının tek araç olarak kaldıkları durumlarda etkilerinin zayıf kalacağı noktasından hareketle bu programları yerel düzlemde kurumların katılımları ile etkili kılabilecek bir Kadın Girişimciliğini Güçlendirme İşbirliği Modeli geliştirilmiştir:

Modelin Amacı: Bu modelin amacı, mikrofinans programlarının yoksulluğu giderme ve girişimciliği geliştirme etkisini arttırmak üzere, mikrofinans kuruluşu çevresinde bir araya getirilecek gönüllü katkıların koordinasyonu aracılı̆̆g ile mikrokrediden yararlanan kadın girişimcilerin güçlendirilmesini sağlayan ortak bir sosyal sorumluluk projesinin temel bileşenlerini bir araya getirmektir.

Modelin Bileşenleri: $\mathrm{Bu}$ model çerçevesinde krediden yararlanan kadınların işlerini gerçek anlamda geliştirebilmeleri için ihtiyaç duydukları çok yönlü destekleri sağlayabilecek yerel kurumların, ortak bir sosyal sorumluluk projesi içinde üstlenebilecekleri belli başlı roller tanımlanmıştır. Güçlendirme projesi bu bileşen kurumlardan herhangi biri tarafından başlatılabilir. Projenin koordinasyonu projeyi başlatan kuruluşta olacaktır.

1. Mikrofinans kuruluşu: $\mathrm{Bu}$ çalışmanın nitel verilerinde görüleceği gibi, mikrokrediden yararlanan kadınların uygulanan programın koşulları ile ilgili çeşitli yakınmaları ve önerileri olmuştur. Bu koşulların iyileştirilmesi için bu tip mikrofinans kuruluşlarının çeşitlenmesine ve hizmetlerin geliştirilmesine ihtiyaç vardır. Mikrofinans programı yürüten kuruluş Türkiye Grameen Mikrofinans Programı veya benzer programlar geliştiren ticari bir banka veya bankalar olabilir. Bu bağlamda ticari bankaların da karlılığı değil sosyal faydayı ön plana alan mikrofinans programları geliştirmesi ve hatta ticari bankaların bir önceki yılın karının belli bir oranını mikrokredi işlemleri için ayırmaya teşvik edilmesi (Apak vd. 2013), önerilen önlemlerden bazılarıdır. Mikrofinans kuruluşunun kredi miktarlarının tespitinde ve geri ödemelerinin düzenlenmesinde kadın girişimcilerin ihtiyaçlarını dikkate alan uygulamalar geliştirmesi nihai başarısı açısından önemli olacaktır.

2. Yerel yönetimler: Büyükşehir belediyeleri veya ilçe belediyeleri önemli kaynaklara sahip olmaları ve giderek daha fazla sosyal belediyecilik faaliyetleri yürütme baskıları ile karşı karşıya olmaları nedeniyle işbirliği modelinin önemli bir bileşeni olabilirler. Başlatılan proje kapsamında seçilen kadın girişimcilerin üretim ve satış faaliyetlerini sürdürebilecekleri uygun mekanların tahsisinde ve hazırlanmasında katkıları vazgeçilmezdir. Nitekim mevcut araştırma kapsamında Alanya Belediyesi'nin sağladığı bu tür imkanlardan söz edilmiştir. Nitel araştırma bulgularında bazı kadınların önerilerinde de yer aldığı gibi, Antalya gibi turistik potansiyeli güçlü kentlerde kadın girişimcilerin turistlere yönelik hediyelik ürünleri kentin kültürel zenginliklerini taşıyan ve yerel ürünlerin bir arada bulunabileceği bir cazibe merkezi haline getirilen bir çarşı, sokak vb. bir merkezde makul maliyetlerle üretip satmalarına imkan tanıyan bir mekanın tahsisi, işbirliği projesinin en önemli başlangıç adımı olacaktır. Bu mekanlara yakın yerlerde kadınlara çocuklarını bırakabilecekleri kreş, etüt vb. kurumsal desteklerin sağlanması da önemli katkı sağlayacaktır.

3. İlgili Sivil Toplum Kuruluşları: Mikrofinans programından yararlanan kadınlar genellikle girişimciliğin gerektirdiği bilgi birikiminden ve deneyimden yoksun bir sosyo-ekonomik kesimi temsil etmektedir. $\mathrm{Bu}$ nedenle, kuruluş amacı kadının güçlendirilmesi, kadın girişimciliğinin güçlendirilmesi, kadın istihdamının arttırılması olan İl Ticaret ve Sanayi Odaları Kadın Girişimciler Kurulları, girişimci/iş kadını dernekleri vb. dernekler, mikrokrediden yararlanan kadınların ihtiyaç duydukları danışmanlık, rehberlik ve desteklerin koordinasyonunu sağla- 
yabilecek önemli bir bileşendir. Bu STK'lar kendi kuruluş amaçları doğrultusunda yürüttükleri faaliyetleri bu işbirliği modeli çerçevesinde daha etkili hale getirip daha güçlü sonuçlar elde edebilirler. Bu İşbirliği Modeli'nin koordinasyon birimi olarak rol oynamaları ve bu çerçevede iş geliştirme, finasman, pazarlama, kooperatifleşme vb. konularda danışmanlık hizmeti verecek daimi bir merkezin kurulması yararlı olacaktır.

4. Yerel üniversitenin ve/veya ortaöğretim kurumlarının ilgili bölümleri: Mikrokrediden yararlanan kadınların genellikle eksik oldukları üretimleriyle ilgili bazı uzmanlık konularında ilgili öğretim kurumlarının desteğini sağlamaları çok önemlidir. Saha çalışmaları sırasında işleriyle ilgili eğitimlere ihtiyaç duyduğunu belirten kadınların oranı yüzde elliyi aşmıştır. Öte yanda, bu konuda bir ihtiyaç açıkça dile getirilmemiş olmakla birlikte, araştırmacıların saha gözlemleri el emeğine dayalı ürünlerin potansiyel müşterilerin tercihlerine uygun tasarımlarla geliştirilmesi gerektiğini ortaya koymuştur. Pazarlanabilir ürün tasarımlarının geliştirilmesi konusunda Güzel Sanatlar Fakültelerinin ve Olgunlaşma Enstitülerinin ilgili bölümlerinden, finansal okuryazarlık ve pazarlama becerilerinin geliştirilmesi için üniversitenin işletmecilikle ilgili bölümlerinden eğitim ve rehberlik sağlanması, kadınların zayıf oldukları alanları telafi ederek işlerini geliştirmelerini sağlayacaktır. Bu eğitimler çerçevesinde, kadınlara yasal haklar, toplumsal cinsiyet eşitliği vb. konularda farkındalık eğitimlerinin verilmesi de yararlı olacaktır. Dolayısıyla eğitim kurumlarının böyle bir işbirliği modelinin içinde yer alması çok önemlidir.

5. Gönüllü Konaklama Tesisleri, Alışveriş Merkezleri veya Süpermarketler: Mikrofinans programından yararlanan kadınların bu araştırmada tespit edilen önemli bir sorunu, ürünlerin üretileceği veya sergileneceği, kalıcı, düşük maliyetli ve potansiyel müşterilere ulaşımı kolaylaştıracak bir satış yeri eksikliğidir. Yörede faaliyet gösteren konaklama tesislerinden özellikle yıl boyu faal olanlar ile alışveriş merkezleri veya süpermarketlerin bir sosyal sorumluluk projesi çerçevesinde, el emeğine dayalı yöresel ürünler üreten girişimci kadınlara sürekli bir satış yeri sağlayabilecekleri düşünülmüştür. Bu tip tesislerde satılacak ürünlerin yörenin kültürel değerlerini pazarlanabilir bir tasarım içinde sunabilen ürünler olması sağlanmalıdır.

$\mathrm{Bu}$ İşbirliği Modeli el emeğine dayalı üretim yapan, ancak ürünlerini istikrarlı bir biçimde pazarlamak için gerekli fiziksel ve ekonomik şartları oluşturmakta zorlanan kadın girişimcilerin güçlendirilmesi için ihtiyaç duyulan kurumsal desteklerin, bileşen kurumlardan herhangi birinin girişimi ve koordinasyonu altında başlatılmasını ve yürütülmesini sağlayacak bir esnekliğe sahiptir. İşbirliğine temel olacak bir protokolün hazırlanması ve bileşenler tarafından müzakere edilerek imzalanması güçlendirme projesinin başlangıcı sayılacaktır. Projenin başarısı ise bileşenlerin üstlendikleri katkıları yerine getirmelerine bağlı olacaktır. Örnek bir projenin başarılı uygulamas farklı coğrafi bölgelerde İşbirliği Modelinin paylaşılarak yaygınlaştırılması için uygun temeli sağlayacaktır. 


\section{KAYNAKÇA}

Altay A. (2007). "Küreselleşen Yoksulluk Olgusunun Önlenmesinde Mikrofinansman Yaklaşımı". Finans Politik \& Ekonomik Yorumlar 44 (2007) 57-67.

Apak S., Husain J., Açıkgöz A. F. \& Eren E. (2013). "Framework for Turkish Commercial Banks to Enter the Microfinance Market”. Journal of Global Strategic Management 7/1 (2013) 5-16.

Balkır Z. G. \& Apaydın D. T. (2011). "Küreselleşmenin Kadın Yoksulluğuna Etkisi”. Kadın ve Yoksulluk Konferansı Bildirileri (2011) 41-50. Ed. Nazan Moroğlu. Avrupa Üniversiteli Kadınlar (UWE) Antalya 2011 Genel Kurulu. İstanbul.

Balkız Ö. I. \& Öztürk E. (2013). "Neo-Liberal Gelişme Anlayışı ve Kadın: Mikro Finans Uygulamaları Kadınları Güçlendiriyor mu?”. MJH III/2 (2013) 1-21.

Barrientos S. \& Kabeer N. (2004). "Enhancing Female Employment in Global Production: Policy Implications”. Global Social Policy 4 (2004) 153-169.

Bircan İ. (2002). "Türkiye'de Yoksulluk ve Kadınlar". Yoksulluk, Şiddet ve İnsan Haklarl (2002) 119127. Ed. Yasemin Özdek. TODAİE İnsan Hakları Araştırma ve Derleme Merkezi. Ankara 2002.

Bornstein D. (1996). The Prize of a Dream: The Story of the Grameen Bank. Chicago 1996.

Buğra A. (2008). Kapitalizm, Yoksulluk ve Türkiye’de Sosyal Politika. İstanbul 2008.

Center for Global Development (2007) Evaluating the Impact of Microfinance, http://www.cgdev.org/ content/article/detail/12338/.

Chowdhury A. (2009). "Microfinance as a Poverty Reduction Tool, A Critical Assessment". DESA Working Paper No. 89ST/ESA/2009/DWP/89, December.

Cömertler N. (2004). “Kadının Penceresinden Yoksulluk”. IV. Aile Şurası: Aile ve Yoksulluk Bildirileri. T.C. Başbakanlık Aile Araştırma Kurumu Başkanlığı Yayınları, 18-20 Mayıs. Ankara 2004.

Denizalp H. (2009). Toplumsal Dönüşüm için Sosyal Girişimcilik Rehberi. STGM 2009.

DPT (2001). "Sekizinci Beş Yıllık Kalkınma Planı: Gelir Dağılımının İyileştirilmesi ve Yoksullukla Mücadele Özel İhtisas Raporu”. Ankara, DPT 2599, http://www.kalkinma.gov.tr/Lists/zel\%20htisas \%20Komisyonu\%20Raporlar/Attachments/76/oik610.pdf.

Ecevit Y. (2001). Kadın Erkek Eşitliğine Doğru Yürüyüş: Eğitim, Çallşma Yaşamı ve Siyaset. TÜSİAD Yayınları. İstanbul 2001.

Ecevit Y. (2003). “Toplumsal Cinsiyetle Yoksulluk İlişkisi Nasıl Kurulabilir? Bu İlişki Nasıl Çalışabilir?”. C.Ü. Tip Fakültesi Dergisi 25 (2003) 83-88.

Ecevit Y. (2007). Türkiye'de Kadın Girişimciliğine Eleştirel Bir Bakış. Uluslararası Çalışma Örgütü, Ankara 2007.

Güneş F. (2011). "Farklı Emek Kategorileri Açısından Kadın Yoksulluğu". Çalışma ve Toplum 2 (2011) 217.

Hashemi S. M. \& Morshed L. (1997). Grameen Bank: A Case Study. Eds. Geoffrey Wood \& Iffath A. Sharif. Who Needs Credit? Poverty and Finance in Bangladesh. New York 1997.

Husain J. (2008). "Role of Micro-Finance Institutions in Reducing World Poverty: An Overview”. The Business Review, Cambridge, 11/1, December (2008) 38-42.

Korkmaz A. \& Korkut G. (2012). “Türkiye'de Kadının İşgücüne Katılımının Belirleyicileri”. Süleyman Demirel Üniversitesi İktisadi ve İdari Bilimler Fakültesi Dergisi 17/2 (2012) 41-65.

Körükmez L. (2008). "Kent Yoksulluğu ile Mücadelede Kadınların Geliştirdiği Stratejiler”. İç. Türkiye’de Yoksulluk Çalışmaları. Derleyen: N. Oktik. İzmir 2008.

Kümbetoğlu B. (2002). "Afetler Sonrası Kadınlar ve Yoksulluk”. Yoksulluk, Şiddet ve İnsan Hakları Hareketi Konferansı 2002 Bildirileri (2002) 129-142. TODAİ İnsan Hakları Araştırma ve Derleme Merkezi. Ankara 2002.

Littelefield E., Morduch J. \& Hashemi S. (2003). "Is Microfinance an Effective Strategy to Reach the Millenium Development Goals?”. Focus Note, CGAP, 24, January, (2003) 1-12.

Mütevellioğlu N. \& Yirmibeşoğlu G. (2011). "Kadının İnsan Hakları, Yoksulluk ve Şiddet”. Kadın ve Yoksulluk Konferansı Bildirileri (2011) 51-64. Ed. Nazan Moroğlu. Avrupa Üniversiteli Kadınlar (UWE) Antalya 2011 Genel Kurulu. İstanbul 2011. 
Özbudun S. (2002). "Küresel Bir Yoksulluk Kültürü mü? İç. Yoksulluk, Şiddet ve İnsan Hakları. Ed. Y. Özdek. Ankara 2002.

Paksoy S. \& Aydoğdu M. H. (2010). "Bölgesel Kalkınmada Girişimciliğin Geliştirilmesi: GAP-GiDEM Örnekleri”. Girişimcilik ve Kalkınma Dergisi 1 (2010) 126-128.

Rhyne E. (1994). A New View of Finance Program Evaluation: The New World of Microenterprise Finance. West Hartford 1994.

Şahin T. (2009). Sosyal Dışlanma ve Yoksulluk Illişkisi. T.C. Başbakanlık Sosyal Yardımlaşma ve Dayanışma Genel Müdürlüğü, Sosyal Yardım Uzmanlık Tezi. Ankara 2009.

Şenses F. (2001). Küreselleşmenin Öteki Yüzü Yoksulluk. İstanbul 2001.

Topgül S. (2013). "Türkiye'de Yoksulluk ve Yoksulluğun Kadınlaşması”. C.Ü. İktisadi ve İdari Bilimler Dergisi 14/1 (2013) 277-296.

Tömen G. (2013). Türkiye Grameen Mikrofinans Programının (TGMP) Kadın Yoksulluğu ve Girişimciliği Üzerine Etkilerinin Antalya İli Bağlamında Araştırılması. Akdeniz Üniversitesi SBE, Yayımlanmamış Yüksek Lisans Tezi. Antalya 2013.

TÜiK (2002). Yoksulluk Çalışması Sonuçları. TÜiK Haber Bülteni. Ankara 2002.

TÜiK (2009). Yoksulluk Çalışması Sonuçları. TÜIKK Haber Bülteni. Ankara 2009.

TÜIK (2012). Veri Tabanı.

TÜİK (2014). Ağustos Hanehalks İsgü̈cü Anketi.

Türkiye Kalkınma Bankası A.Ş. (2007). Mikrofinansman. Ekonomik ve Sosyal Araştırmalar Müdürlüğü. Ankara 2007.

Ulutaş-Ünlütürk, Ç. (2009). "Yoksulluğun Kadınlaşması ve Görünmeyen Emek”. Çalışma ve Toplum 2 (2009) 25-40.

World Bank (2004). Food Programme Yearly Report. Washington, USA 2004.

Yumuşak İ. \& Bilen M. (2008). "The Comparative Analysis of Human Development Levels of Transition Economies”. KMU IIBBF Dergisi 10 (2008) 1-15.

Yunus M. (2009). “A Partial Marvel”. The Economist, July 16.

\section{İnternet Kaynakları}

www.ashoka.org

www.beytussebap.gov.tr

www.csgb.gov.tr

www.europa.eu.int

www.grameen-info.org

http://www.kagider.org

www.kamer.org.tr

www.kedv.org.tr

www.ksgm.gov.tr

www.sydgm.gov.tr

www.tgmp.net

www.tobb.org.tr

www.tüsev.org.tr

www.undp.org.tr 